
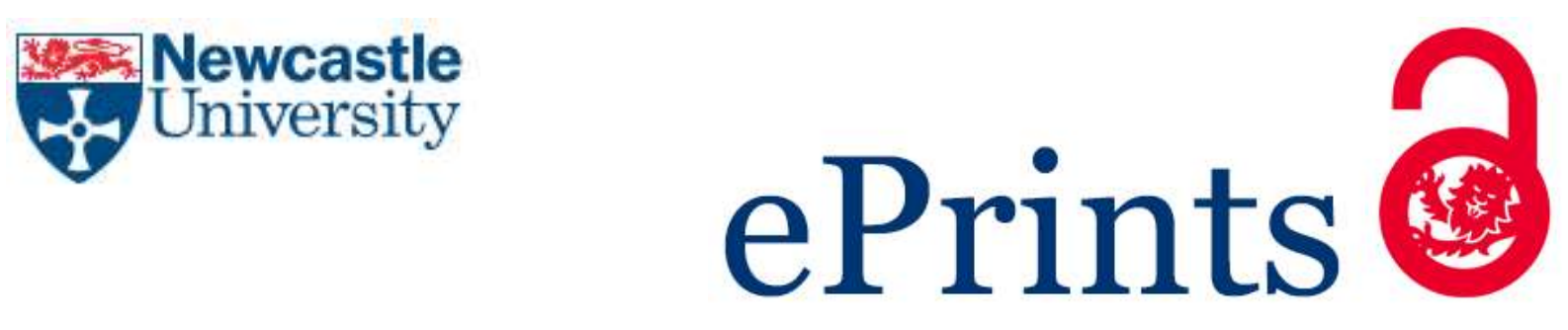

Abdelsalam O, Dimitropoulos P, Elnahass M, Leventis S. Earnings Management Behaviors under Different Monitoring Mechanisms: The Case of Islamic and Conventional Banks. Journal of Economic Behavior and Organization 2016

DOI: http://dx.doi.org/10.1016/j.jebo.2016.04.022

Copyright:

(C) 2016. This manuscript version is made available under the CC-BY-NC-ND 4.0 license

Date deposited:

$24 / 05 / 2016$

Embargo release date:

20 November 2017

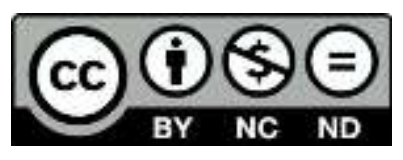

This work is licensed under a

Creative Commons Attribution-NonCommercial-NoDerivatives 4.0 International licence 


\title{
Earnings Management Behaviors under Different Monitoring Mechanisms: The Case of Islamic and Conventional Banks
}

\author{
Omneya Abdelsalam (Durham University, UK) \\ Panagiotis Dimitropoulos (University of Peloponnese, Greece)* \\ Marwa Elnahass (Newcastle University, UK) \\ Stergios Leventis (International Hellenic University, Greece)
}

\section{Acknowledgement:}

We thank two anonymous reviewers for constructive feedback and direction. We also thank Gerry Steele for valuable editing comments. We thank the participants of the JEBO Islamic Finance Conference, June 2014, for constructive comments and suggestions. We acknowledge financial support from the El Shaarani Research Centre and research assistance by Antonios Chantziaras and Ioanna Baltira in the data collection section.

* Corresponding Author: Panagiotis Dimitropoulos, University of Peloponnese, Greece, email: dimitrop@uop.gr, Tel: $+302731089677-\operatorname{ext} 3111$ 


\title{
Earnings Management Behaviors under Different Monitoring Mechanisms: The Case of Islamic and Conventional Banks
}

\begin{abstract}
We investigate the impact of organizational religiosity on the earnings quality of listed banks in the Middle East and North Africa region. We analyze Islamic banking institutions, which operate within strict religious norms and extended accountability constraints, and compare them with their conventional counterparts during 2008-2013. We find that Islamic banks are less likely to manage earnings and that they adopt more conservative accounting policies. Based on these findings, we argue that religious norms and moral accountability constraints in these organizations have a significant impact on financial reporting quality and agency costs, which has implications for both regulators and market participants.
\end{abstract}

Keywords: Financial reporting quality, earnings management, conservatism, Islamic banks, MENA countries, agency costs.

JEL codes: M41, G15, G21, G28 


\section{Introduction}

A well-established branch of the literature indicates that religion has an important role in shaping the economic behavior of both individuals and organizations (Barro and McCleary, 2003; Stulz and Williamson, 2003; Lehrer, 2004; Vitell, 2009; Abdelsalam and El-Komi, 2014; Leventis et al., 2016). Within the realm of accounting, for instance, religiosity appears to operate as an institutionalized control mechanism that influences managerial decisions on corporate financial reporting (Callen and Fang, 2013). While the impact of religious social norms on economic behavior has been discussed in advanced financial contexts, such as in the United States (Callen and Fang, 2013), this issue has received little attention in emerging economies with prevailing Islamic religious norms. An ideal setting for such an investigation is the Middle East and North Africa (MENA) region.

A distinguishing institutional characteristic of the MENA region is the strong influence that religion has on the banking sector. This region has the highest concentration of Islamic banks in the world (PricewaterhouseCoopers [PwC], 2012; Thomson Reuters, 2015). ${ }^{1}$ These banks are founded on strict religious principles, which shape their rules and codes of practice. ${ }^{2}$ The Islamic finance industry is approaching $\$ 2.5$ trillion in worth, and its value is growing at a phenomenal rate (Ernst and Young, 2015).

The developmental role of banks assumes transparent and credible financial reporting. Therefore, questions about the quality of financial information undermine the contribution of banks to the proper functioning of the financial markets (Barro and McCleary, 2003; Callen and Fang, 2013). In the current study, we investigate whether organizational religiosity significantly affects the quality of financial reporting. The importance of this investigation extends beyond our sample and responds to prior calls for further research on the role of social norms and culture (i.e., values extracted from religious scriptures) on core economic matters (Stulz and Williamson, 2003; Acemoglu et al., 2005).

\footnotetext{
1 The regions' Islamic banks represent $50 \%$ (US\$2,766,510) of the total assets of Islamic banks $(\$ 5,533,020)$ in the 22 countries that have a dual banking system (conventional and Islamic banks). This is based on 10 years' (20032012) data accessed through the Bureau VAN DIJK Bankscope database.

2 We refer to Islamic banks throughout our discussions as those banks that follow Shariah (Islamic jurisprudence) in their business transactions.
} 
Islamic banks are based on a constrained ${ }^{3}$ model of finance that prohibits Riba (usury), Gharar (excessive uncertainty), and Maysir (speculations) and encourages the sharing of profits, losses, and risks. The constraints of the Islamic banking model imply the existence of two directions for agency costs. On the one hand, depositors in Islamic banks are contracted as investment account holders (IAHs). In practice, however, Islamic banks' managers have full control over the investment of depositors' funds; IAHs lack board representation and cannot directly monitor bank performance. The absence of IAHs' representation on the board of directors is an additional agency cost borne by the depositors. On the other hand, the religious adherence of Islamic banks implies a possible reduction in agency costs through organizational moral accountability constraints. Previous literature argues that the opportunistic behavior of corporate actors (i.e., managers) may be suppressed within an environment that incorporates organizational moral values (Kaptein, 2011; Ha-Brookshire, 2015). Islamic banks are also subject to an extra layer of governance represented by the Shariah supervisory board ${ }^{4}$ (SSB). The SSB approves and reports on Islamic banks' compliance with moral values. Moreover, the concept of Islamic accountability extends the moral responsibility of the managers and board members of Islamic banks beyond conventional legal liability (Beekun and Badawi, 2005; Belal et al., 2015).

Against this background, we examine the impact of organizational religiosity on the quality of financial reporting by banks in the MENA region. We use accounting conservatism $^{5}$ and earnings management (manipulation) ${ }^{6}$ as measures of accounting quality. Our sample comprises 600 observations of listed banks in the MENA region during 2008-2013. Our empirical results show that Islamic banks are more conservative and less prone to earnings management. Our results also reveal that these banks are

\footnotetext{
${ }^{3}$ In addition, these banks are not permitted to invest in businesses with core products or activities that are impermissible in Islam, such as alcohol, pork, weapons of mass destruction, gambling, adult entertainment products, and cloning. ${ }^{4}$ The SSB contains scholars holding specialist religious knowledge of Islamic jurisprudence. The SSB's main duties include: (i) introducing the Shariah guidance for conducting banking business, (ii) issuing a statement in the annual report on whether the bank has been conducting its business in compliance with Shariah, and (iii) highlighting any breaches of Shariah rules.

${ }^{5}$ Accounting conservatism specifies a higher threshold for recognizing gains and a lower one for recognizing losses, with the aim of reporting strict profits and net assets (Basu, 1997; Khan and Watts, 2009).

${ }^{6}$ Earnings management indicates the use of subjective judgment by management in financial reporting and in structuring transactions in ways that alter financial reports either to mislead (conceal) the underlying economic performance of the company or to influence contractual outcomes that depend on reported accounting numbers (Healy et al., 1999).
} 
more likely to employ the four largest international audit firms (the Big Four) to conduct audits compared with their conventional counterparts, which signals higher quality of audits. We conclude that Islamic banks operate within a governance framework that enhances financial reporting quality.

We contribute to the literature in several ways. First, we demonstrate the importance of organizational religiosity on managerial decision-making in less-developed capital markets in which institutional monitoring and enforcement devices are generally relatively weak. Secondly, our findings that religious norms operate as a significant monitoring mechanism extend what is known on how social norms can affect core economic matters, with particular implications for global regulations (e.g., auditing, enforcement of financial reporting). Finally, our study furthers the current debate on the role of religion with regard to accountability, transparency, and business ethics.

Our findings highlight important implications for investors and auditors in the global banking industry. Investors should be aware that additional institutional factors (i.e., organizational religiosity) are associated with enhanced financial reporting quality and reduced agency costs. Auditors may regard the operation of religiosity as a monitoring mechanism and adjust the depth and the width of their audit procedures accordingly (Leventis et al., 2016). Finally, regulators should account for the relationship between religiosity and financial reporting quality when attempting to regulate the global banking industry (see Guiso et al., 2006). Based on the results of the current study, managers of conventional banks operating in the MENA region need to increase the quality of their financial reporting. This goal can be achieved with additional and/or stronger corporate governance mechanisms.

The rest of the paper is organized as follows. The next section describes the theoretical background and develops testable hypotheses. The third section presents the data selection and methodology used. The fourth section demonstrates the empirical findings and sensitivity analysis. The final section concludes the paper.

\section{Theoretical background and hypotheses development}

Islamic banks are substantially different from conventional banks in terms of finance models, investment modes, and contracts (see Table 1). These differences significantly 
affect their corporate governance structures, agency conflicts, and overall accountability.

\section{INSERT TABLE 1 HERE}

Irrespective of the bank type (conventional or Islamic), agency conflicts represent an ultimate cost that can influence financial reporting quality within the banking industry. An underlying reason for this circumstance is generally related to the complex agent-principal (manager-shareholder) relationship and to the unique governance structure in banks (Leventis et al., 2013). Thus, agency costs are expected to be more pronounced in banks because of a high level of opacity in contractual and reporting practices (i.e., the unobserved quality of loan portfolios) (Mülbert, 2009), excessive risk-taking behavior given the highly leveraged cost structures (Mehran et al., 2011), and greater information asymmetries between insiders (managers) and outsiders (stakeholders) (Morgan, 2002). These interrelated qualities make bank performance difficult to monitor (Levine, 2004; Leventis et al., 2013). Furthermore, government bailouts and deposit insurance funds tend to provide greater leeway for banks to engage in excessive risk taking or more reckless economic behavior because both moral hazard and regulatory penalties are low (Macey and O’Hara, 2003).

Overall, the peculiarities of banking operations generate multiple agency costs and weaken the effectiveness of several governance mechanisms to mitigate them. Agency conflicts are even more complex within the context of Islamic banking. In addition to the traditional conflicts, that is, agent-principal, majority-minority shareholding, and shareholders-creditors (see Fama and Jensen, 1983; Jensen and Smith, 1985; Bowie and Freeman, 1992; La Porta et al., 1999), Islamic banks face other conflict: the one between the depositors and the managers. This conflict instigates further agency costs and increased legal liability for managers in these banks. Since Islamic banks are prohibited from charging interest, which is considered usury, depositors are contracted as IAHs through an equity-based investment contract (Mudarabah). This contract requires profits from investments to be shared between the bank and the IAHs according to a mutually agreed-upon proportion. Investment losses are completely borne by the IAHs (depositors) unless they arise from misconduct or negligence by the bank 
(Aggarwal and Yousef, 2000; Belal et al., 2015). In practice, the majority of Islamic banks do not empower IAHs to directly monitor their investment through representation on the board of directors. This increases the risk of exploitation of the IAHs by the bank managers (Abdel Karim and Archer, 2002) and may heighten their agency costs. Because the IAHs cannot directly monitor their investment funds, they must track them indirectly through published financial information.

The depositor-manager conflict implies additional agency costs in Islamic banks and highlights a greater need to strictly control for bias in financial reporting, which serves as one of the main sources of information for IAHs (Abdel Karim and Archer, 2002; Chapra and Ahmed, 2002). On the other hand, previous research argues that organizational religiosity induces social norms ${ }^{7}$ that suppress opportunistic behavior of bank managers (Weaver and Agle, 2002). Religiously oriented organizations are expected to follow strict moral constraints that shape the particular context of their economic operations. These constraints are also expected to enhance organizational morality. Previous literature argues that when corporations have well-defined moral guidelines or structures that all members can easily follow, the morally responsible behavior of individuals within the corporations improves (Kaptein, 2011; HaBrookshire, 2015).

In addition, the religious concept of Islamic accountability extends the moral accountability of Islamic banks' actors (managers, board of directors, and SSB members) beyond their legal liability. This accountability compels these actors to pursue the best interests of the bank's wider stakeholders as well as to maximize the value of the shareholders' and depositors' (IAHs') investments and to protect them (see Beekun and Badawi, 2005; Belal et al., 2015). These actions fulfill the religious obligation of Amana (trust), which requires the banks' actors to behave according to

\footnotetext{
${ }^{7}$ Social norms are the external rules "shared by a group, sustained both by sanctions and by emotions of guilt and shame, whose primary characteristic is that it enjoins its followers to forgo selfish benefits in the name of group benefits" (Festre, 2010, p. 514). Individuals tend to comply with the understandings and expectations of their peer groups to avoid sanctions associated with non-adherence to prevailing values and beliefs. Moreover, accepted attitudes are usually rewarded with social approval and strong community support (Leventis et al., 2013). Prior literature demonstrates that economic behavior actually depends on the beliefs or actions of the community (Romer, 1984). In this sense, social norms constitute the main driving forces or motivational mechanisms for market participants (Dyreng et al., 2012).
} 
the principles of $A d l$ (justice), Qist (balance), and Ihsaan (perfection) (Beekun and Badawi, 2005). Therefore, we expect managers of Islamic banks, as actors in religiously oriented organizations, to prioritize ethical choices in measuring and reporting financial transactions. In other words, greater moral accountability constraints on Islamic banks' actors are expected to conditionally lead to lower agency costs in these banks. This moral accountability is likely to reduce risk-taking behavior (more conservatism) and discourage or mitigate earnings management practices. Accordingly, higher transparency is conjectured to exist for this banking sector in comparison with conventional counterparts.

Moreover, all Islamic banks appoint an SSB, which operates as an additional governance mechanism. The SSB's primary objective is to ensure that Islamic banks operate in accordance with the ethos of Shariah (Beekun and Badawi, 2005). The existence of this second layer of governance is expected to additionally limit opportunities for financial misstatements and consequently moderate the higher agency costs in Islamic banks (Mensah, 2014).

Figure 1 illustrates the governance framework of Islamic banks and the interactions between a bank's various actors (i.e., managers, the board of directors, and the SSB) and its major stakeholders (i.e., depositors, creditors, and shareholders). It also depicts the impact of organizational religiosity on agency costs and the reporting behavior of Islamic banks.

\section{INSERT FIGURE 1 HERE}

Against this theoretical framework, we expect that Islamic banks may exhibit important differences from conventional banks in terms of earnings management and accounting conservatism. To measure the quality of financial reporting (Walker, 2013), we develop testable hypotheses on conservatism and earnings management respectively.

Conservatism is an important valuation concept in accounting because it requires one to proceed cautiously if the measurement of financial numbers is uncertain (Epstein and Jermakowicz, 2007). According to Basu (1997), conservatism calls for a higher verifiability threshold for recognizing gains compared to losses. Conservatism is beneficial for financial statements because it reduces managerial opportunism, 
mitigates agency problems associated with managerial investment decisions (Ahmed and Duellman, 2007; Basu, 2005), enables efficient debt agreements in the context of asymmetric information (Ball and Shivakumar, 2005; García Lara et al., 2009), reduces litigation, and assists in the efficient valuation of claims (LaFond and Watts, 2008). Thus, conservatism motivates managers to cut losses earlier and abandon poorly performing projects (García-Lara et al., 2009).

Accounting conservatism can be particularly important for banks because of the sector's complexities, intense information asymmetries, opacity, and contracting particularities (Levine, 2004; Leventis et al., 2013). Regulators prefer conservative financial reporting by firms to avoid complications or litigation if they become insolvent (Watts, 2003). In particular, central bankers prefer prudent practices, such as increased loan provisions, during economic upturns (Turner, 1997; Leventis et al., 2013).

Religious organizations are likely to be more conservative and risk averse than other organizations (Osoba, 2003; Hilary and Hu, 2009). The double-layer governance and the moral accountability constraints of Islamic banks' managers are expected to moderate the higher agency conflicts in these banks. These managers are expected to operate in ways that avoid excessive social and moral costs (Callen and Fang, 2013; Belal et al., 2015), and therefore they are less likely to withhold bad news for personal gain. Accordingly, we hypothesize that

H1: Islamic banks are more conservative than conventional banks in their financial reporting practices.

Scheiner (1981) provides evidence that banks employ loan loss provisions (LLPs) as an important tool for earnings management. Also, Ma (1988) and Greenawalt and Sinkey (1988) report that bank managers tend to raise LLPs during periods of high operating income in order to decrease the volatility of reported earnings. This conclusion is also supported by several studies focusing on the U.S. banking industry (see Healy and Wahlen, 1999; Liu et al., 1997; Beaver and Engel, 1996; Wahlen, 1994; Leventis and Dimitropoulos, 2012), which all conclude that banks use LLPs as a tool for aggressive earnings management (manipulation). Studies using non-U.S. bank 
samples arrive at similar conclusions (Anandarajan et al., 2007; Perez et al., 2008). Beatty et al. (2002) demonstrate that banks, in addition to using LLPs, manage reported earnings by manipulating security gains and losses. Shrieves and Dahl (2003) and Agarwal et al. (2007) conclude that Japanese banks used security gains and LLPs to manage earnings during 1985-1999. Hazera (2005) reaches the same conclusion for Mexican banks, and Shen and Chih (2005) report evidence of significant income management (manipulation) in several countries.

Nevertheless, managers of religiously affiliated organizations are more likely to adopt certain social norms associated with anti-manipulative behavior. Dyreng et al. (2012) argue that religion is an institutionalized control mechanism that affects individual and corporate attitudes. Moreover, McGuire et al. (2012) report a significant association between firms being headquartered in areas with strong religious, social, and ethical codes and lower incidences of financial reporting irregularities. Grullon et al. (2010) find that firms located in counties in the United States with higher levels of religiosity are less likely to be named in class action securities lawsuits or to engage in backdating options. They are also less likely to grant excessive compensation packages to their managers or to practice aggressive earnings management. These findings align with previous research studies arguing that individuals with strong religious beliefs tend to reject morally questionable decisions in any business environment (McCullough and Willoughby, 2009; Vitell, 2009).

Consequently, we argue that religiously oriented banks are less likely than conventional banks to manipulate both the flow and the quality of corporate information (Barro and McCleary, 2003; Callen and Fang, 2013). Therefore, organizational religiosity acts as a powerful deterrent to making accounting misstatements and availing of earnings management opportunities. We thus argue that Islamic banks operating under strict religious norms report financial numbers of enhanced quality as measured by lower earnings management. Our second research hypothesis is formed as follows:

H2: Islamic banks are associated with lower earnings management compared to conventional banks.

\section{Data and methodology}




\subsection{Data selection procedure}

To test our predictions, we focused on the MENA region, which has the highest concentration of Islamic banks in the world. Drawing upon different data sets, namely, Datastream, Thomson Reuters' Zawya, and Bloomberg, we found 158 listed banks in the MENA region. These banks were further filtered considering (a) availability of corporate governance (i.e., board of directors and ownership structure) data for the entire period under investigation (2008-2013) and (b) availability of at least four banks in each country included for analysis (Beck et al., 2013). Our final sample contained financial data from 12 MENA countries: Bahrain, Egypt, Jordan, Kuwait, Lebanon, Morocco, Oman, Qatar, Saudi Arabia, Syria, Tunisia, and the United Arab Emirates (UAE). This sample included 100 banks, 24 of which are denoted as Islamic and 76 of which are conventional, yielding 600 bank-year observations for analysis. All financial data were extracted from Bankscope and The Financial Times' Banker databases, while corporate governance and ownership data were extracted from Thomson Reuters' Zawya. The final sample distribution is presented in Appendix A.

\subsection{Measuring accounting conservatism}

Our first measure of accounting quality refers to accounting conservatism, represented by the timely recognition of LLPs relative to non-performing loans (Leventis et al., 2013). Nichols et al. (2009) argue that a bank's loan loss accounting reflects its credit risk management behavior and can create substantial information asymmetry between management and shareholders. Within this framework, LLPs are expenses reflecting managers' valuation of future loan losses. Thus, banks that engage in conservative accounting recognize LLPs that are larger and in more timely manner relative to the variations in non-performing loans (Nichols et al., 2009; Leventis et al., 2013). To test for the differences in the timeliness of Islamic banks and conventional banks in recognizing LLPs, we followed Nichols et al. (2009) and Leventis et al. (2013) by associating LLPs with lagged, contemporaneous, and future changes in nonperforming loans $\left(\Delta \mathrm{NPL}_{\mathrm{it}-1}, \Delta \mathrm{NPL}_{\mathrm{t}} \text {, and } \Delta \mathrm{NPL}_{\mathrm{it}+1} \text {, respectively }\right)^{8}$. We controlled for

\footnotetext{
${ }^{8}$ Nonperforming - loans refer to loans that are due but not yet paid by debtors for at least 90 days. They are either in default or close to default.
} 
differences in loan charge-offs ${ }^{9}$ for both current $\left(\mathrm{LCO}_{\mathrm{it}}\right)$ and future years $\left(\mathrm{LCO}_{\mathrm{it}+1}\right)$, and we formalized this test by estimating Ball and Shivakumar's (2005) model, as adopted by Nichols et al. (2009):

$$
\begin{aligned}
L L P s_{i t} & =a_{0}+a_{1} \Delta N P L_{i t-1}+a_{2} \Delta N P L_{i t}+a_{3} \Delta N P L_{i t+1}+a_{4} L C O_{i t}+a_{5} L C O_{i t+1} \\
& +a_{6} I B s_{i t} * \Delta N P L_{i t-1}+a_{7} I B s_{i t} * \Delta N P L_{i t}+a_{8} I B s_{i t} * \Delta N P L_{i t+}+a_{9} I B s_{i t} * L C O_{i t} \\
& +a_{10} I B s_{i t} * L C O_{i t+1}+a_{11-18} G O V_{i t}+a_{19-28} C O N T R O L_{i t}+a c_{29-33} Y R \_D U M M I E S+e_{i t}[1]
\end{aligned}
$$

Where:

LLPs $\quad=\quad$ ratio of loan loss provisions for year $t$ to total loans in year $t$ 1

$\Delta \mathrm{NPL}=$ change in non-performing loans between two years, deflated by total loans in year $t-1$

$\mathrm{LCO}=$ loan charge-offs for year $t$, deflated by total loans in year $t-1$

IBs $\quad=$ dummy receiving 1 for Islamic banks, and 0 otherwise

GOV $=$ a vector of governance and ownership variables

CONTROL $=$ a vector of control variables

YR_DUMMIES = year dummies

For Model [1], our primary predictions are that the coefficients $a_{6}, a_{7}$, and $a_{8}$ on $\mathrm{IBSit}^{*} \Delta \mathrm{NPLit-1}, \mathrm{IBSit}^{*} \Delta \mathrm{NPLit}$, and $\mathrm{IBSit}^{*} \Delta \mathrm{NPLit+1}$ are positive. This indicates that Islamic banks recognize larger or more timely LLPs relative to changes in nonperforming loans compared to conventional banks. Consistent with prior studies (Nichols et al., 2009; Leventis et al., 2013), we expect the coefficients $a_{1}, a_{2}, a_{3}, a_{4}$, and $a_{5}$ on $\Delta \mathrm{NPL}_{\mathrm{it}-1}, \Delta \mathrm{NPL}_{\mathrm{it}}, \Delta \mathrm{NPL} \mathrm{Lit}_{\mathrm{t}+1}, \mathrm{LCO}_{\mathrm{it}}$, and $\mathrm{LCO}_{\mathrm{it}+1}$ to have positive signs. We expect the lagged present and future changes in non-performing loans $\left(\triangle \mathrm{NPL}_{\mathrm{it}-1}, \Delta \mathrm{NPL} \mathrm{L}_{\mathrm{it}}\right.$, and $\Delta \mathrm{NPL}_{\mathrm{it}+1}$ ) to be positively related to LLPs (Kanagaretnam et al., 2010). We also expect net loan charge-offs ( $\mathrm{LCO}_{\mathrm{it}}$, and $\left.\mathrm{LCO}_{\mathrm{it}+1}\right)$ to be positively related to LLPs because loan charge-offs provide information about the future collectability of loans (see Beaver and

\footnotetext{
${ }^{9}$ Loan charge-offs refer to uncollectible loans that are subsequently written off. This is a type of bad debt expense that should be charged to the income statement.
} 
Engel, 1996; Kanagaretnam et al., 2010). Although the Nichols et al. (2009) model requires continuous time-series data, which constrains the sample size (Beatty and Liao, 2011), it is the most appropriate research design for measuring conservatism in the banking industry (Leventis et al., 2013).

\subsection{Measuring earnings management}

Following Leventis and Dimitropoulos (2012), we employ three different metrics for earnings management. The first measure identifies small positive income as a target of earnings management. Burgstahler and Dichev (1997), Leuz et al. (2003), and Barth et al. (2008) use the frequency of small positive net income as an indicator of managing earnings. The underlying expectation is that managers aim to report a small positive net income rather than negative net income for various reasons, such as the manipulation of the stock market, avoidance of debt covenants, and even the achievement of earnings targets for receiving bonuses (Leventis et al., 2013). Based on hypothesis 2, we expect Islamic banks to report a small positive net income less frequently than conventional banks.

To test this assertion, we followed Burgstahler and Dichev (1997), Lang et al. (2003), and Barth et al. (2008) and estimated a dummy variable SPOS that equals 1 if net income deflated by lagged total assets is between 0 and 0.01 for each given year, and 0 otherwise. We then introduced SPOS as the dependent variable in the following logit regression model:

$$
\begin{aligned}
\text {SPOS }_{i t}= & a_{0}+a_{1} E B T_{i t}+a_{2} I B S_{i t}{ }^{*} E B T_{i t}+a_{3-10} G O V_{i t}+c_{11-19} C_{\text {CONTROL }} t \\
& + \text { c20-24YR_DUMMIES }+e_{i t}
\end{aligned}
$$

Where:

EBT = earnings before taxes deflated by lagged total assets. The remaining variables are as previously defined.

A negative coefficient on the $\mathrm{IBs}_{\mathrm{it}} * \mathrm{EBT}_{\mathrm{it}}$ variable indicates that Islamic banks report small positive income less frequently than conventional banks.

Our second metric for earnings management is based on using LLPs and realized security gains and losses as mechanisms for aggressive earnings management 
(Anandarajan et al., 2007; Beatty et al., 2002; Leventis and Dimitropoulos, 2012). LLPs and realized security gains and losses combine a nondiscretionary component, which brings loan loss allowances to an acceptable level, and a discretionary portion, which is closely regulated (Cornett et al., 2009). Therefore, in order to produce a salient estimate of the earnings management behavior of banks via the manipulation of LLPs, we estimated the discretionary part of LLPs and realized security gains and losses. We followed Cornett et al. (2009) and Leventis and Dimitropoulos (2012) and estimated the following fixed-effect OLS regression model for calculating the discretionary part of LLPs:

$$
\begin{aligned}
L_{O S S}=a_{t} & +b_{1} \ln T A_{i t}+b_{2} N P L_{i t}+b_{3} L L R_{i t}+b_{4} L O A N R_{i t}+b 5 L O A N C_{i t}+b_{6} L O A N I_{i t} \\
& +\varepsilon_{i t}
\end{aligned}
$$

Where:

$$
\begin{array}{lll}
\text { LOSS } & = & \text { loan loss provisions deflated by total loans } \\
\operatorname{lnTA} & = & \text { natural logarithm of total assets } \\
\mathrm{NPL} & = & \text { ratio of nonperforming loans to total loans } \\
\text { LLR } & = & \text { ratio of loan loss reserves to total loans } \\
\text { LOANR } & = & \text { ratio of real estate loans to total loans } \\
\text { LOANC } & = & \text { ratio of commercial and industrial loans to total loans } \\
\text { LOANI } & = & \text { ratio of consumer and installment loans to total loans }
\end{array}
$$

The discretionary component of LLPs (DLLP) is the error term from the above regression. Following Leventis and Dimitropoulos (2012), we standardized the error term by the ratio of total loans to total assets and defined DLLPit as ( $\varepsilon^{*}$ LOANS)/ASSETS, where LOANS is total loans and ASSETS is total assets.

The next step is to estimate the discretionary part of realized security gains and losses (RSGL). Following Cornett et al. (2009), we estimated the following fixed effects regression model as

$$
R S G L_{i t}=a_{t}+b_{1} \ln T A_{i t}+b_{2} U R S G L_{i t}+\varepsilon_{i t}
$$

Where: 


$\begin{array}{lll}\text { RSGL } & = & \text { realized security gains and losses deflated by total assets } \\ \operatorname{lnTA} & = & \text { natural logarithm of total assets } \\ \text { URSGL } & = & \text { unrealized security gains and losses deflated by total assets }\end{array}$

The error term of regression (b) is the discretionary part of the realized security gains and losses. Our measure of earnings management (EM) is the difference between the discretionary part of RSGL and the discretionary part of LLPs. Higher levels of EM increase earnings and vice versa; that is, higher levels of EM correspond to increased earnings management.

The EM proxy is estimated from the previous step and introduced as the dependent variable in the following regression model in which all independent variables are defined as before:

$$
\begin{aligned}
E M_{i t}=a_{0} & +a_{1} E B T_{i t}+a_{2} I B s_{i t} * E B T_{i t}+a_{3-10} G O V_{i t}+c_{11-19} C O N T R O L_{i t} \\
& +c_{20-24 Y R \_D U M M I E S}+e_{i t}
\end{aligned}
$$

We expect a negative coefficient on the IBsit $* E^{*} T_{\text {it }}$ variable, which indicates Islamic banks exhibit less aggressive earnings management behavior.

Our third and final measure of earnings management is discretionary accruals estimated from the Jones (1991) model and modified by Yasuda et al. (2004) for banking institutions. We ran the following regression to obtain the discretionary part of the total accruals of the banks:

$$
A C C R_{t}=c_{1}\left(1 / T A_{t-1}\right)+c_{2}\left(\Delta O I_{t} / T A_{t-1}\right)+c_{3}\left(B R E_{t} / T A_{t-1}\right)+e_{t}
$$

Where:

$\begin{array}{ll}\text { ACCR } & =\begin{array}{l}\text { total accruals estimated as the difference between net income and } \\ \text { operating cash flows }\end{array} \\ \mathrm{TA} & =\text { total assets } \\ \Delta \mathrm{OI} & =\text { change in a bank's operating income between } \mathrm{t}-1 \text { to } \mathrm{t} \\ \mathrm{BRE} & =\text { bank's premises and equipment. }\end{array}$


All variables and the intercept are deflated with lagged total assets to reduce heteroskedasticity in the error term. The residuals from equation (c) are denoted as the discretionary portion (DACC) of total accruals, which depends on managerial discretion and is our primary variable of interest. In the following step, we introduce it as the dependent variable:

$$
\begin{aligned}
D A C C_{i t}= & a_{0}+a_{1} E B T_{i t}+a_{2} I B S_{i t} * E B T_{i t}+a_{3-10} G O V_{i t}+c_{11-19} C O N T R O L_{i t} \\
& +c_{20-24 Y R \_D U M M I E S}+e_{i t}
\end{aligned}
$$

All models include year dummies to capture time-specific effects and to offset the problem of heteroskedasticity in the error term. As in the previous models, we expect a negative coefficient on the $\mathrm{IBSit}^{*} \mathrm{EBT}_{\text {it }}$ variable, which indicates that Islamic banks exhibit a lower magnitude of discretionary accruals and have less earnings management. All the models were tested for potential endogeneity (Kennedy, 2008; Koutsoyiannis, 1977) by applying the Hausman (1978) simultaneity specification test, as suggested by Pindyck and Rubinfeld (1991). Our results indicate no serious endogeneity problems: our dependent variable does not lead to biased or inconsistent OLS estimates.

\subsection{Governance and ownership variables}

All the models include variables to reflect governance and ownership structure for both Islamic and conventional banks. According to Brown et al. (2011), board and ownership structures are significant determinants of accounting quality and managerial accounting choices. For this reason, we introduced variables to reflect CEO duality, board independence, and state and foreign ownership. For definitions see Appendix B.

Some prior literature suggests that CEO duality enhances corporate value through a thorough knowledge of the strategies and the operations of the firm (Brown et al., 2011). However, where accounting issues are concerned, other literature provides strong evidence that boards independent from the CEO perform their monitoring role and mitigate earnings management behavior better (see Klein, 2002; Mitchell, 2005; Chang and Sun, 2010). That is to say, CEO duality is associated with more earnings management and less conditional conservatism. 
Board independence is measured as the ratio of independent members to total board members. A large body of research shows a strong negative correlation between board independence and earnings management. Marnet (2008), Klein (2002), Persons (2006), Iqbal and Strong (2010), Dimitropoulos and Asteriou (2010), and Beekes et al. (2004) all argue that independent boards contribute toward the integrity and quality of financial statements. Consequently, we expect a negative coefficient on that variable in the earnings management models and a positive coefficient in the conservatism Model [1].

In addition, prior literature (Megginson et al., 1994; Wang and Yung, 2011; Shleifer, 1998) demonstrates that state-owned firms are associated with higher earnings management. However, Laidroo (2009) and Wang and Yung (2011) report the opposite effect. Therefore, we form no strong expectation on the impact of state ownership. Beyond earnings management, state ownership has a significant impact on firms' accounting conservatism. The general finding is that state ownership has a negative impact on accounting conservatism (Cullinan et al., 2012).

Finally, we consider foreign ownership. According to Laidroo (2009), foreign owners tend to be large international firms that operate in several countries. With less of a need to acquire outside financing from the local market, subsidiary firms may have diminished accounting quality. However, $\mathrm{Xu}$ et al. (2012) find that internationally owned firms present the highest accounting quality across all types of ownership structure groups (private, state, employee, etc.).

\subsection{Control variables}

Our first control variable is bank size (SIZE), measured as the natural logarithm of total assets. Because analysts tend to follow larger banks (Leventis and Dimitropoulos, 2012), these banks are less likely to engage in aggressive earnings management (Cornett et al., 2009). Thus, we expect a negative coefficient on the SIZE variable for the earnings management models. LaFond and Watts (2008) argue that conservatism is less evident for larger firms because they provide more publicly available information and use multiple information dissemination techniques. Givoly et al. (2007) find that asymmetric timeliness of earnings for large firms differs from that of small firms. In contrast, Callen et al. (2010) argue that large firms, facing lower operational uncertainty, demand greater accounting conservatism. 
The second control variable is leverage (LEV), which is measured as the ratio of total debt to common equity. Riskier banks may inflate accounting earnings for reasons related to capital adequacy requirements and regulatory scrutiny (Cornett et al., 2009; Leventis and Dimitropoulos, 2012). Thus, we expect a positive coefficient on LEV. In addition, we use a control for tier 1 capital adequacy ratio (CAP). Regulators scrutinize capitalized banks less, which allows more opportunities for managing earnings (Cornett et al., 2009). However, the managers of low-capitalized firms might have more incentives to manage earnings in order to avoid sanctions. Anandarajan et al. (2007) provide significant results on the impact of CAP on earnings management behavior. Consequently, the association between capital adequacy and both earnings management and conservatism may not be monotonic. Thus, we cannot infer any predictions about the sign of this coefficient.

We control for banks' growth opportunities using the market-to-book ratio (GRW). Lai (2009) indicates that firms with increased growth opportunities are less likely to report discretionary accruals, especially when they experience increased monitoring. Banks are generally more regulated and more closely monitored compared with other institutions, and they may be associated with less earnings management. Therefore, we expect the coefficient on GRW to be negative. Additionally, Roychowdhury and Watts (2007) and LaFond and Roychowdhury (2008) argue that the market-to-book ratio reflects the composition of equity value, which is determined by the investment opportunities of the firm and the past asymmetric timeliness of earnings. Therefore, we expect GRW to have a positive association with conservatism.

We also control for audit quality by including a dummy variable (AUDQ) that indicates that a bank is audited by one of the Big Four audit firms, which are expected to produce high-quality financial statements (Gul et al., 2006; Park and Pincus, 2001). In addition, Leventis et al. (2013) suggest that banks audited by the Big Four audit firms have a higher level of LLPs relative to nonperforming loans, indicating higher conditional conservatism. Consequently, we expect a negative coefficient on this variable for the earnings management models and a positive coefficient for the conservatism model. Furthermore, we control for bank financial performance, measured as net cash flow from operating activities deflated by average total assets (CFO). High-performing firms that tend to use more conservative accounting (Ahmed 
and Duellman, 2007; Leventis et al., 2013) are less motivated to manage their accounting numbers. Accordingly, we expect the coefficient on $\mathrm{CFO}$ to be positive for the conservatism model and negative for the earnings management model. We also control for lagged loan loss allowance deflated by total loans (LLAt-1) on the conditional conservatism model since we expect banks with high LLA it-1 $_{1}$ to have lower LLPs in the current period (if banks that are over-reserved recognize lower provisions in the next period) (Liu and Ryan, 2006; Leventis et al., 2013).

Our last set of control variables comprises country-specific variables. The first is a dummy receiving unity (1) for a country in the Gulf Cooperation Council (GCC) group, and zero (0) otherwise. This dummy variable controls for differences in accounting quality among the monarchies and wealthy Gulf countries, where banks may have different incentives for accounting quality. A second dummy (TURC) is unity (1) for banks originating in Egypt, Syria, or Tunisia, and zero (0) otherwise. The TURC variable represents three countries that experienced political turmoil during the years 2011-2013, which significantly affected their economy. Leuz et al. (2003) document how corruption is a significant determinant of corporate accounting quality; therefore, the third country variable is the level of corruption (CORRUPT) taken from the World Bank's World Governance Indicators. CORRUPT takes values between 0 and 100, with the highest value indicating a higher level of corruption among the government and officials.

\section{Empirical results}

\subsection{Descriptive statistics and correlations}

Table 2 presents the descriptive statistics of the sample variables for the full sample. Islamic banks are found to have lower mean values of all earnings management measures relative to conventional banks. Islamic banks report small positive income (between 0.00 and 0.01) less frequently, and they have fewer discretional accruals as well as lower discretionary LLPs relative to discretionary security gains and losses. These results are the first indication that Islamic banks present relatively higher accounting quality, confirming results reported by Elnahass et al. (2014). Islamic banks also have relatively lower government and foreign ownership than conventional banks, 
and Islamic banks separate the roles of the CEO and board chairman more often. Board independence is similar between the two categories of banks. With respect to the remaining variables, Islamic banks have a less-risky loan portfolio, as illustrated by fewer changes in nonperforming loans, loan charge-offs, and loan loss allowances and more LLPs. In addition, Islamic banks are more capitalized, have less negative stock returns and are less leveraged, which aligns with the findings of Beck et al. (2013).

\section{INSERT TABLE 2 ABOUT HERE}

Table 3, Panel A presents the Pearson correlation coefficients. Islamic banks are negatively correlated with all earnings management measures, but the correlation is significant only with SPOS, indicating that Islamic banks tend to smooth their income towards positive numbers less frequently. In addition, Islamic banks are negatively correlated with foreign and government ownership as well as with board independence. Moreover, Islamic banks are negatively correlated with LEV but positively correlated with AUDQ and CAP, suggesting that Islamic banks are more capitalized and likely to have been audited by the Big Four audit firms.

Panel B of Table 3 presents the Pearson correlation coefficients for the conditional conservatism model. Islamic banks are positively and significantly correlated with LLPs, indicating that they tend to recognize more LLPs. Furthermore, SIZE is negatively correlated with FOR_OWN, DUAL, and BODIND. Also, LEV is found to be positively correlated with $\Delta \mathrm{NPL}_{\mathrm{t}+1}$, indicating that highly leveraged banks tend to have more future nonperforming loans. Finally, AUDQ is negatively correlated with GOV_OWN and DUAL, indicating that Big Four audit firms tend not to audit stateowned banks and banks with more concentrated management control.

\section{INSERT TABLE 3 ABOUT HERE}

\subsection{Results on conservatism and earnings management}

The results from the estimation of Model [1] are presented in Table 4. The regression F-stat is highly significant. Islamic banks recognize LLPs based more on the changes between past and future nonperforming loans instead of loan charge-offs because the coefficients on IBs $* \Delta \mathrm{NPL} \mathrm{Lit}_{-1}$ and $\mathrm{IBs}^{*} \Delta \mathrm{NPL}_{\mathrm{it}+1}$ are positive and significant. This result 
can be interpreted as an increase by a unity of future non-performing loans leading to an approximately 3\% increase to current LLPs. The results show that Islamic banks follow a more conservative accounting policy for recognizing LLPs. This could be explained by Islamic banks basing their loan loss provisioning decisions on the actual changes in nonperforming loans and on their managers' expectations about the nonperforming loans in the following year, before the nonperforming loans are charged-off on the bank's income statement. This result is in line with expectations for the impact of both the moral accountability constraints and the added governance in Islamic banks on reducing agency costs to depositors, creditors, and shareholders of Islamic banks. This implies a higher conservatism and higher accounting quality in Islamic banks.

In addition, the coefficients on the variables of the current change of nonperforming loans $\left(\triangle N P L_{i t}\right)$ and the current and future level of loan charge-offs $\left(L C O_{i t}, L C O_{i t+1}\right)$ are positive and statically significant, which is similar to findings in prior research and our expectations. These results imply that an increase by a unity in current nonperforming loans $\left(\triangle N P L_{i t}\right)$ and loan charge-offs $\left(L C O_{i t}\right)$ leads to increases of $4.8 \%$ and approximately $8.2 \%$ in LLPs, respectively, which are economically significant. This increase of LLPs generated from $\triangle N P L i t$ and $L C O_{i t}$ indicates significant degree of accounting conservatism.

With regard to the governance and ownership variables, the only significant coefficient is positive for the IBs*BODIND interaction variable. This is consistent with the assumption that Islamic banks with increased board independence recognize more LLPs, which aligns with previous literature regarding the positive impact of board independence on accounting quality (Brown et al., 2011; Beekes et al., 2004). The results indicate that Islamic banks are more conservative reporters of LLPs. Finally, the only significant control variables are the lagged level of loan loss allowances (LLA), audit quality (AUDQ), and growth (GRW), which are positive.

\section{INSERT TABLE 4 ABOUT HERE}

Table 5 presents the empirical findings from the three earnings management model estimations. The Wald $\chi^{2}$ (as a test for the statistical significance of each coefficient in the model) is significant for the logit model (SPOS), and the F-stats are significant for 
the EM and DACC models. As the main variable of interest in the interaction between IBs and earnings before taxes, IBs*EBT is negative and statistically significant in all earnings management models. This is consistent with the assumption that Islamic banks report small positive income less often, have less discretionary accruals, and experience a relatively small difference between discretionary LLPs and RSGL. These results indicate that Islamic banks are less likely to manipulate their income numbers. The IBs*EBT coefficient under the EM model is negative and significant (-0.049). Compared to the insignificant EBT coefficient, the IBs*EBT coefficient result can be interpreted as Islamic banks manipulating LLPs and security gains and losses less often to achieve earnings targets. Overall, we argue that the quality of financial reporting of Islamic banks is enhanced by their moral accountability constraints and more broadly religious norms constraints in restricting earnings management.

The variable of state ownership (GOV_OWN) is negative and significant in the SPOS and DACC models. This is consistent with the assumption that an increase in state ownership is associated with less earnings management, either through reporting small positive income or manipulating discretionary accruals. This finding corroborates arguments from prior literature that firms under state ownership have less need for outside financing, which in turn reduces motives for earnings management (Wang and Yung, 2011; Ding et al., 2007; Laidroo, 2009). The coefficient on state ownership for Islamic banks (IBs*GOV_OWN) is not significant. Foreign ownership, however, may be correlated with the decision of bank managers to manage discretionary LLPs for achieving earnings targets. The coefficient on FOR_OWN is positive and significant in the EM model, which signals that banks with higher foreign ownership have more discretionary LLPs relative to RSGL, by up to $0.5 \%$. This result suggests that these banks manipulate their income statements more often, which accords with Laidroo (2009). However, the opposite effect applies for Islamic banks (IBs*FOR_OWN). The respective coefficient is negative and significant in the EM and SPOS models, suggesting that Islamic banks manage their financial statements less often, even under the control of a foreign investor. This finding corroborates our previous arguments that Islamic banks are associated with enhanced accounting quality.

The finding is still supported when we look at the variables for the composition of the board of directors (i.e., CEO duality and board independence). The respective 
coefficient for Islamic banks (IBs*DUAL) is non-significant. Regarding board independence, the coefficient for IBs*BODIND is negative and significant for Islamic banks, indicating that board independence enhances their financial reporting quality compared to conventional banks. The coefficient for CEO duality (DUAL) is positive and significant in the EM model, indicating that boards with CEO duality (which indicates lower board monitoring) engage more in earnings management. This leads to the recommendation that in conventional banks, additional governance mechanisms should be employed, in conjunction with board composition to improve their financial reporting quality.

Regarding the control variables, only SIZE, LEV, and CAP are positive and significant. In addition, banks in GCC countries report relatively higher discretionary accruals than those in non-GCC countries, indicating that banks in GCC countries overstate their earnings. The positive coefficients for LEV and CAP are in accordance with the regulatory capital management theory, and they suggest that riskier banks (high LEV) tend to artificially inflate accounting earnings for reasons related to capital adequacy requirements and regulatory scrutiny (Cornett et al., 2009; Leventis and Dimitropoulos, 2012). Furthermore, well-capitalized banks (high CAP) have greater opportunities for earnings management because they undergo less scrutiny by regulators (Cornett et al., 2009). Finally, the SIZE coefficient is negative and significant, which aligns with our expectations. This finding supports the argument that small-sized banks engage in manipulative techniques in order to achieve earnings targets that international and local investors and debtors consider appropriate.

The overall results, based on the three tested empirical models for EM, shed light on the influence of the additional governance and the moral accountability constraints within Islamic banks. They act as important mechanisms in mitigating opportunistic behavior and hence, controlling the overall agency costs in these banks compared to their conventional counterparts, which usually operate under a single layer of governance.

\section{INSERT TABLE 5 ABOUT HERE}

Moreover, we test the impact of bank type on the decision of the auditor selection, as a measure of audit quality (Landsman et al., 2009). Studies in prior literature argue 
that auditors influence earnings quality since their role is to restrict incidents of financial misstatement and managerial discretion (Dechow et al., 2010). We estimate a logit regression model using a dummy (AUDQ) as the dependent variable that receives unity (1) for banks audited by one of the world's four largest international audit firms (Big Four), and zero (0) otherwise. The other variables are the control and governance variables used in the previous models. Therefore, the logit model has the following form:

$$
\begin{aligned}
A U D Q_{i t} & =a_{0}+a_{1} E B T+a_{2} I B s+a_{3} G O V \_O W N+a_{4} F O R \_O W N+a_{5} D U A L \\
& +a_{6} B O D I N D+a_{7} S I Z E+a_{8} L E V+a_{9} C A P_{t}+a_{10} G R W+\mathrm{a}_{11} C F O_{t} \\
& +a_{12} G C C+\mathrm{a}_{13} T U R C_{t}+a_{14-18} Y R \_D U M M I E S+e_{i t}[5]
\end{aligned}
$$

The results are presented in Table 6 . The coefficient for the IBs variable is positive and significant: Islamic banks tend to hire the Big Four audit firms for their statutory audits. This result is in line with the main finding of this study; that is, Islamic banks report earnings of higher quality. These results imply that the auditor selection decision is likely to have a substantial influence on promoting higher earnings quality and conservatism in Islamic banks.

\section{INSERT TABLE 6 ABOUT HERE}

\subsection{Sensitivity analyses}

We performed 10 sensitivity tests to assess the validity of our findings. In the first test, following Leventis et al. (2013), we checked for any potential effect that the control variables (SIZE, CAP, CFO, GRW, LEV, and AUDQ) might have on the conservatism measure by including interaction terms between each control variable and our measure of conservatism. Therefore, all control variables were interacted with $\triangle \mathrm{NPL}_{\mathrm{it}-1}, \triangle \mathrm{NPL} \mathrm{L}_{\mathrm{i}}, \triangle \mathrm{NPLit+1}, \mathrm{LCO}_{\mathrm{it}}$, and $\mathrm{LCO}_{\mathrm{it}+1}$ in Model [1]. The results are unaffected.

Second, to control for possible bias arising from the sign on the difference in nonperforming loans (whether the change is positive or negative), we re-estimated Model [1], allowing the coefficient on the change in nonperforming loans ( $\triangle \mathrm{NPL}$ ) to 
vary. Untabulated findings provided qualitatively similar results to those presented in Table 3.

Third, following Clinch and Magliolo (1993), who argue that discretionary LLPs and RSGL should not be combined into a single earnings management variable, we reestimated Model [3] to include discretionary LLPs and realized security gains and losses separately as our measure of earnings management. The results remain qualitatively unchanged.

Fourth, in order to capture any biases in the estimation of discretionary accruals, we eliminated the upper and lower $1 \%$ of the absolute value of discretionary accruals and re-estimated Model [3] as in Leventis and Dimitropoulos (2012). This had no significant impact on the main findings.

Fifth, we removed some of the restrictions in the sample selection procedure and included countries that have fewer than four banks in their utilized databases. The results remain relatively unchanged. Nevertheless, the explanatory power of the models is significantly reduced, probably due to a higher sample variability.

Sixth, we included additional country-related variables in all models, such as GDP growth, rule of law regulatory quality, government efficiency, and bank concentration ratio to control for additional factors. The results are unaffected.

Seventh, all models were re-estimated after we changed the definition of some control variables. GOV_OWN and FOR_OWN were replaced by dummies receiving unity (1) for those banks that have foreign and state ownership above 50\%. SIZE was re-estimated as the logarithm of the market value of equity, and LEV and GRW were re-measured as long-term debt to total assets and the annual percentage change of interest income, respectively. The results are unaffected.

Eighth, we controlled for the impact of the 2011 political turmoil in the Middle East and tested whether it affected the accounting quality of Islamic banks and conventional banks. While the political turmoil was more prevalent in specific MENA counties, we further considered whether its wider impact in this region was more pronounced for specific types of banks and conducted a sensitivity test. Thus, we re-estimated all models after separating the sample into the pre-turmoil (2008-2010) and post-turmoil (2011-2013) periods. The results indicate that the conservatism of Islamic banks increased during the post-turmoil period, but no change occurred for conventional 
banks. Interestingly, conventional banks seemed to exercise more earnings management via discretionary accruals and LLPs than Islamic banks after the turmoil period.

Ninth, we re-estimated Model [2] by dividing our sample into countries belonging to the GCC group, which are the most affluent in the MENA region, and countries with political turmoil during 2011 and 2013 (i.e., Egypt, Syria, and Tunisia). The findings suggest that only Islamic banks in the countries that experienced political turmoil exercised less income smoothing than conventional banks, a finding that corroborates the result in Table 5 .

Tenth, we controlled for the impact of adopting the incurred loan loss model ${ }^{10}$ employed by Islamic banks in Jordan, Bahrain, and Qatar as opposed to the expected loan loss model ${ }^{11}$, which is currently proposed by the International Financial Reporting Standards (IFRS). We found that Islamic banks seem to report less discretionary accruals and to be more conservative in relation to conventional banks. These results confirm our initial findings on Islamic banks' enhanced earning quality. Also, banks with government ownership are associated with less discretionary accruals; in contrast, conventional banks with foreign ownership manipulate their earnings more often in comparison to Islamic banks.

\section{Conclusion}

This paper examines the impact of religious norms on the quality of financial reporting of MENA-listed banks during 2008-2013. We drew upon both agency and social norm theories. We also discussed the unique governance framework of Islamic banks, featuring additional depositor-manager conflict, the extra layer of governance (SSB), and the moral accountability constraints in these banks. In that context, we expected that the opportunistic behavior by corporate actors would be suppressed.

Our main findings demonstrate that Islamic banks are more conservative because they recognize more LLPs relative to non-performing loans and loan charge-offs.

\footnotetext{
${ }^{10}$ The incurred loan loss model is based on estimating loan loss provisions for incurred losses as a result of an objective evidence of impairment for a financial asset.

${ }^{11}$ The expected loan loss model estimates loan loss provisions based on a forward-looking approach for potential credit losses during economic downturns.
} 
Additionally, Islamic banks are less likely to manage earnings than conventional banks because they are less likely to report small positive income that is close to zero and they report fewer cases of discretionary accruals. Additionally, they engage the Big Four audit firms more frequently.

Accordingly, we suggest that the strict religious orientation of Islamic banks motivates managers to raise the quality of financial reporting and to reduce agency costs for stakeholders, including depositors, creditors, and shareholders.

Our study is of particular importance because of the unique institutional characteristics of the Islamic finance industry, the rapid increase in its size, and the interconnectedness of the global economic system. The contribution of the paper is threefold. First, we show that religious norms play a major role in influencing managerial decision-making in the context of less-developed capital markets, which are characterized by weak control institutions and relatively ineffective enforcement mechanisms. We also expand the extant literature by moving beyond the U.S. context. Second, our findings substantiate the view that social norms affect financial reporting and auditing at the global level. Finally, we bring to the fore contexts in which Islamic values predominate, illuminating the global role of religious norms in accountability, transparency, and business ethics.

The implications of our research are important for market participants and regulators. Investors and analysts should factor into their analyses the important role of strong religious adherence in improving the quality of financial reporting and reducing agency costs. Moreover, auditors and regulators should view religious adherence and the moral accountability constraints as being complementary mechanisms to statutory auditing; they may therefore, adjust their efforts accordingly.

Our study has certain limitations that create avenues for future research. First, our study is limited to the MENA region, which reduces our ability to generalize important findings. Future researchers could expand on our research to cover Islamic countries in other parts of the world and thereby enrich the understanding offered by this study. Secondly, our research design does not focus on the individual, but rather on the impact of religiosity at the level of the bank. Future researchers could employ interviews and questionnaires with management staff to interpret the impact of individual religiosity on decision-making. 


\section{References}

Abdel Karim, R., Archer, S., 2002. Islamic Finance: Innovation and Growth. Euromoney Publications, London.

Abdelsalam, O., El-Komi, M., 2014. Islamic finance: An introduction. J. Econ. Behav. Org. 103(July), S1-S3.

Acemoglu, D., Johnson, S., Robinson, J. A. 2005. Institutions as a fundamental cause of long-run growth. Handbook of Economic Growth, 1, 385-472.

Aggarwal, R.L., Yousef, T., 2000. Islamic banking and investment financing. J. Mon. Cred. Ban. 32, 93-120.

Agarwal, Sumit, Souphala Chomsisengphet, Chunlin Liu, and S. Ghon Rhee. 2007. Earnings management behaviors under different economic environments: Evidence from Japanese banks. Int. Rev. of Econ. \& Financ. 16, 429-443.

Ahmed, A.S., Duellman, S., 2007. Accounting conservatism and board of director characteristics: an empirical analysis. J. Account. Econ. 43, 411-437.

Anandarajan, A., Hasan, I., McCarthy, C., 2007. Use of loan loss provisions for capital, earnings management and signaling by Australian banks. Account Financ. 47, 357379.

Ball, R., Shivakumar, L., 2005. Earnings quality in UK private firms: Comparative loss recognition timeliness. J. Account. Econ. 39, 83-128.

Barro, R., McCleary, R., 2003. Religion and economic growth. Am. Sociol. Rev. 68, 760781.

Barth, M.E., Landsman, W.R., Lang, M.H., 2008. International accounting standards and accounting quality. J. Account. Res. 43, 467-498.

Basu, S., 1997. The conservatism principle and the asymmetric timeliness of earnings. J. Account. Econ. 24, 3-37.

Basu, S., 2005. Discussion of conditional and unconditional conservatism: Concepts and modelling. Rev. Account. Stud. 10, 311-321.

Beatty, A., Liao, S., 2011. Do delays in expected loss recognition affect banks' willingness to lend? J. Account. Econ. 52, 1-20.

Beatty, A.L., Ke, B., Petroni, K.R., 2002. Earnings management to avoid earnings declines across publicly and privately held banks. Account. Rev. 77, 547-570.

Beaver, W.H., Engel, E., 1996. Discretionary behaviour with respect to allowances for loan losses and the behaviour of stock prices. J. Account. Econ. 22, 177-206.

Beck, T., Demirgüç-Kunt, A., Merrouche, O., 2013. Islamic vs. conventional banking: Business model, efficiency and stability. J. Ban. Financ. 37, 433-447.

Beekes, W., Pope, P., Young, S., 2004. The link between earnings timeliness, earnings conservatism and board composition: Evidence from the UK. Corp. Gov.: An Int. Rev., 12, 47-59.

Beekun, R.I., Badawi, J.A., 2005. Balancing ethical responsibility among multiple organizational stakeholders: The Islamic perspective. J. Bus. Ethics. 60, 131-145.

Belal, A.R., Abdelsalam, O., Nizamee, S.S., 2015. Ethical reporting in Islamic bank Bangladesh limited (1983-2010). J. Bus. Ethics, 129, 769-784. Bowie, N. E., Freeman, R. E. 1992. Ethics and Agency Theory: An Introduction. New York: Oxford University Press.

Brown, P., Beekes, W., Verhoeven, P., 2011. Corporate governance, accounting and finance: A review. Account Financ. 51, 96-172. 
Burgstahler, D., Dichev, I., 1997. Earnings management to avoid earnings decreases and losses. J. Account. Econ. 24, 99-126.

Callen, J., Fang, X., 2013. Religion and stock price crash risk. J. Financ. Quant. Anal. 50, 169-195.

Callen, J.L., Segal, D., Ole-Kristian, H., 2010. The pricing of conservative accounting and the measurement of conservatism at the firm-year level. Rev. Account. Stud. 15, $145-178$.

Chang, J.C., Sun, H.L., 2010. Does disclosure of corporate governance structures affect firms' earnings quality? Rev. Account. Financ. 9, 212-243.

Chapra, M.U., Ahmed, H., 2002. Corporate Governance in Islamic Financial Institutions, Islamic Development Bank. Islamic Research and Training Institute- King Fahad, Saudi Arabia, Periodical Document No. 6, 1-170.

Clinch, G., Magliolo, J., 1993. CEO compensation and components of earnings and earnings management in bank holding companies. J. Account. Econ. 16, 241-272.

Cornett, M.M., McNutt, J.J., Tehranian, H., 2009. Corporate governance and earnings management at large US bank holding companies. J. Corp. Financ. 15, 412-430.

Cullinan, C.P., Wang, F., Wang, P., Zhang, J., 2012. Ownership structure and accounting conservatism in China. J. Int. Account. Audit. Tax. 21, 1-16.

Dechow, P.M., Myers, L.A., Shakespeare, C., 2010. Fair value accounting and gains from asset securitizations: a convenient earnings management tool with compensation side-effects. J. Account. Econ. 49, 2-25.

Dimitropoulos, P., Asteriou, A., 2010. The effect of board composition on the informativeness and quality of annual earnings: empirical evidence from Greece. Res. Int. Bus. Financ. 24, 190-205.

Ding, Y., Zhang, H., Zhang, J., 2007. Private vs state ownership and earnings management: Evidence from Chinese listed companies. Corp. Gov.: An Int. Rev., 15, 223-238.

Dyreng, S., Mayew, W.J., Williams, C.D., 2012. Religious social norms and corporate financial reporting. J. Bus. Financ. Account. 39, 845-875.

Elnahass, M., Izzeldin, M., Abdelsalam, O., 2014. Loan loss provisions, bank valuations and discretion: a comparative study between conventional and Islamic banks. J. Econ. Behav. Org. 103(July), S106-S173.

Epstein, B.J., Jermakowicz, E.K., 2007. IFRS 2007: Interpretation and application of International Financial Reporting Standards. Wiley Publications, Hoboken, NJ.

Ernst and Young. 2015. World Islamic Banking Competitiveness Report 2014-15. Retrieved from http://www.ey.com/EM/en/Industries/Financial-Services/Banking--Capital-Markets/EY-world-islamic-banking-competitiveness-report-2014-15.

Fama, E., Jensen, M., 1983. Separation of ownership and control. J. Law .Econ. 26, 301325.

Festre, A. 2010. Incentives and social norms: A motivation-based economic analysis of social norms. J. Econ. Surv. 24, 511-538.

García Lara, J.M., García Osma B., Penalva, F., 2009. Accounting conservatism and corporate governance. Rev. Account. Stud. 14, 161-201.

Givoly, D., Hayn, C., Natarajan, A., 2007. Measuring reporting conservatism. Account. Rev. 82, 65-106.

Greenawalt, M.B., Sinkey, J.F., 1988. Bank loan loss provisions and the income smoothing hypothesis: an empirical analysis, 1976-1984. J. Financ. Serv. Res. 1, 301-318. 
Grullon, G., Kanatas, G., Weston, J., 2010. Religion and corporate (mis) behaviour (Working Paper). Houston, TX: Rice University. Retrieved from http://dx.doi.org/10.2139/ssrn.1472118.

Guiso, L., Sapienza, P., Zingales, L., 2006. Does culture affect economic outcomes? J. Econ. Perspect. 20, 23-48.

Gul, F.A., Tsui, J.S.L., Dhaliwal, D.S., 2006. Non-audit services, auditor quality and the value relevance of earnings. Account Financ. 46, 1-21.

Gul, F.A., Wah, L.K., 2002. Insider entrenchment, board leadership structure and informativeness of earnings. Working paper. Retrieved from http://dx.doi.org/10.2139/ssrn.304399.

Ha-Brookshire, J., 2015. Toward moral responsibility theories of corporate sustainability and sustainable supply chain. J. Bus. Ethics. doi:10.1007/s10551-015-2847-2.

Hausman, J.A., 1978. Specification tests in econometrics. Economet., 46, 1251-1271.

Hazera, A., 2005. Bank earnings management in emerging market economies: The case of Mexico. Adv. Int. Account. 18, 73-95.

Healy, P.M., Wahlen, J.M., 1999. A review of the earnings management literature and its implications for standard setting. Account. Horiz. 13, 365-383.

Hilary, G., Hui, K.W., 2009. Does religion matter in corporate decision making in America? J. Financ. Eco. 93, 455-473.

Iqbal, A., Strong, N., 2010. The effect of corporate governance on earnings management around UK rights issue. Int. J. Manage. Financ. 6, 168-189.

Javers, E. (2011, February 12). Religion, Not money, often motivates corporate whistleblowers. Retrieved from http://www.cnbc.com/id/41494697.

Jensen, M.C., Smith, C.W. 1985. Stockholder, Manager, and Creditor Interests: Applications of Agency Theory, in Recent Advances in Corporate Finance, E.I. Altman and M.G. Subrah- manyan (eds.), Homewood, IL, Richard D. Irwin.

Jones, J., 1991. Earnings management during import relief investigations. J. Account. Res., 29, 193-228.

Kaptein, M., 2011. Toward effective codes: Testing the relationship with unethical behaviour. J. Bus. Ethics, 99, 233-251.

Kanagaretnam, K., Krishnan, G.V., Lobo, G.J., 2010. An empirical analysis of auditor independence in the banking industry. Account. Rev., 85, 2011-2046.

Kennedy, P., 2008. A Guide to Econometrics (6th ed.). Wiley-Blackwell.

Khan, M., Watts, R.L., 2009. Estimation and empirical properties of a firm-year measure of accounting conservatism. J. Account. Econ. 48, 132-150.

Klein, A., 2002. Audit committee, board of director characteristics, and earnings management. J. Account. Econ. 33, 375-400.

Koutsoyiannis, A., 1977. Theory of Econometrics. 2nd ed. MacMillan, London.

LaFond, R., Roychowdhury, S., 2008. Managerial ownership and accounting conservatism. J. Account. Res. 46, 101-135.

LaFond, R., Watts, R.L., 2008. The information role of conservatism. Account. Rev. 83, 447-478.

Lai, K., 2009. Does audit quality matter more for firms with high investment opportunities? J. Account. Public Pol. 28, 33-50.

Laidroo, L., 2009. Association between ownership structure and public announcements' disclosures. Corp. Gov.: Int. Rev. 17, 13-34. 
Landsman, W.R., Nelson, K.K., Rountree, B.R., 2009. Auditor switches in the pre- and post- Enron eras: Risk or realignment? .Account. Rev. 84, 531-558.

Lang, M., Raedy, J., Yetman, M., 2003. How representative are firms that are cross listed in the United States? An analysis of accounting quality. J. Account. Res. 41, 363386.

La Porta, R., Lopez-de-Silane, F., Shleifer, A., 1999. Corporate ownership around the world. J. Financ. 54, 471-517.

Lehrer, E.L., 2004. Religion as a determinant of economic and demographic behaviour in the United States. Pop. Develop. Rev. 30, 707-726.

Leuz, C., Nanda, D., Wysocki, P.D., 2003. Earnings management and investor protection: an international comparison. J. Financ. Econ. 69, 505-527.

Leventis, S., Dimitropoulos, P., 2012. The role of corporate governance in earnings management: experience from US banks. J. Appl. Account. Res. 13, 161-177.

Leventis, S., Dimitropoulos, P., Owusu-Ansah, S., 2013. Corporate governance and accounting conservatism: evidence from the banking industry. Corp. Govern. .Int. Rev. 21, 264-286.

Leventis, S., Dedoulis, E., Abdelsalam, O. 2016. The Impact of religiosity on audit pricing. J. Bus. Ethics, 1-26.

Levine, R., 2004. The corporate governance of banks: A concise discussion of concepts and evidence. World Bank Policy Research Working Paper 3404. The World Bank, Washington, DC.

Liu, C., Ryan, S., 2006. Income smoothing over the business cycle: Changes in banks' coordinated management of provisions for loan losses and loan charge-offs from the pre-1990 bust to the 1990s boom. Account. Rev. 81, 421-441.

Liu, C., Ryan, S., Wahlen, J., 1997. Differential valuation implications of loan loss provisions across bank and fiscal agents. Account. Rev. 72, 133-146.

Ma, C.K., 1988. Loan loss reserve and income smoothing: The experience in the US banking industry. J. Bus. Financ. Account. 15, 487-497.

Macey, J.R., O'Hara, M., 2003. The corporate governance of bank. FRBNY Econ. Policy Rev. 9, 91-107.

Marnet, O., 2008. Behaviour and rationality in corporate governance. Int. J. Behav. Account. Financ. 1, 4-22.

McCullough, M.E., Willoughby, B.L.B., 2009. Religion, self-regulation and self-control: association, explanation and implications. Psychol. Bull. 135, 69-93.

McGuire, S., Omer, T.C., Sharp, N.Y., 2012. The impact of religion on financial reporting irregularities. Account. Rev. 87, 645-673.

Megginson, W.L., Nash, R.C., Van Randenborgh, M., 1994. The financial and operating performance of newly privatized firms: an international empirical analysis. J. Financ. 49, 403-452.

Mehran, H., Morrison, A., Shapiro, J., 2011. Corporate governance and banks: what have we learned from the financial crisis? FRBNY Staff Reports No. 502.

Mensah, Y.M., 2014. An analysis of the effect of culture and religion on perceived corruption in a global context. J. Bus. Ethics., 121, 255-282.

Mitchell, L., 2005. Structural roles, CEOs and the missing link in corporate governance. Brooklyn Law Rev. 70, 1313-1368.

Morgan, D.P. 2002. Rating banks: risk and uncertainty in an opaque industry. Am. Econ. Rev. 92, 874-888. 
Mülbert, P.O., 2009. Corporate governance of banks. Eur. Bus. Org. Law Rev. 10, 411436.

Nichols, D.G., Wahlen J.M., Wieland, M.M., 2009. Publicly traded versus privately held: Implications for conditional conservatism in bank accounting. Rev. Account. Stud. $14,88-122$.

Osoba, B., 2003. Risk preferences and the practice of religion: evidence from panel data. Unpublished Working Paper, West Virginia University.

Park, C., Pincus, M., 2001. Internal versus external equity funding sources and earnings response coefficients. Rev. Quant. Financ. Account. 16, 33-52.

Perez, D., Salas-Fumás, V., Saurina, J., 2008. Earnings and capital management in alternative loan loss provision regulatory regimes. Eur. Account. Rev. 17, 423-445.

Persons, O.S., 2006. Corporate governance and non-financial reporting fraud. The J. Bus. Econ. Stud. 12, 27-41.

Pindyck, R.S., Rubinfeld, D.L., 1991. Econometric models and economic forecasts. 3rd ed. International. McGraw-Hill, Inc., New York.

PricewaterhouseCoopers (PwC). 2012. Changes to accounting for loan losses: Practical considerations for banks. Financial Report (February).

Romer, D. 1984. The theory of social custom: A modification and some extensions. Q. J. Econ. 99, 717-727.

Roychowdhury, S., Watts, R., 2007. Asymmetric timeliness of earnings, market-to- book and conservatism in financial reporting. J. Account. Econ. 44, 2-31.

Scheiner, J.H., 1981. Income smoothing: an analysis in the banking industry. J. Bank Res. 12, 119-123.

Shen, C.H., Chih, H.L., 2005. Investor protection, prospect theory, and earnings management: an international comparison of the banking industry. J. Bank. Financ. 29, 2675-2697.

Shleifer, A., 1998. State versus private ownership. J. Econ. Perspect. 12, 133-150.

Shrieves, R.E., Dahl, D., 2003. Discretionary accounting and the behaviour of Japanese banks under financial distress. J. Bank. Financ. 27, 1219-1243.

Stulz, R., Williamson, R., 2003. Culture, openness, and finance. J. Financ. Econ. 70, 313349.

Thomson Reuters. (2015). State of Global Islamic Economy 2014-2015 report. Retrived from http://www.flandersinvestmentandtrade.com/export/sites/trade/files/news/342150 121095027/342150121095027_1.pdf

Turner, J.H., 1997. The institutional order. Addison-Wesley Educational Publishers, New York.

Vitell, S.J., 2009. The role of religiosity in business and consumer ethics: a review of the literature. J. Bus. Ethics, 90, 155-167.

Wahlen, J.M., 1994. The nature of information in commercial bank loan disclosures. Account. Rev. 69, 455-478.

Walker, M., 2013. How far can we trust earnings numbers? what research tells us about earnings management. Account. Bus. Res. 43, 445-481.

Wang, L., Yung, K., 2011. Do state enterprises manage earnings more than privately owned firms? the case of China. J. Bus. Financ. Account. 38, 794-812.

Watts, R., 2003. Conservatism in accounting. Part I: explanations and implications. Account. Horizons. 17, 207-221. 
Weaver, G.R., Agle, B.R., 2002. Religiosity and ethical behaviour in organizations: a symbolic interactionist perspective. Acad. Manage. Rev. 27, 77-97.

Xu, W., Wang, K., Anandarajan, A., 2012. Quality of reported earnings by Chinese firms: the influence of ownership structure. Adv. Account. 28, 193-199.

Yasuda, Y., Okuda, S., Konishi, M., 2004. The relationship between bank risk and earnings management: evidence from Japan. Rev. Quant. Financ. Account. 22, 233-248. 
Figure 1: Corporate Governance Framework for Islamic Financial Institutions

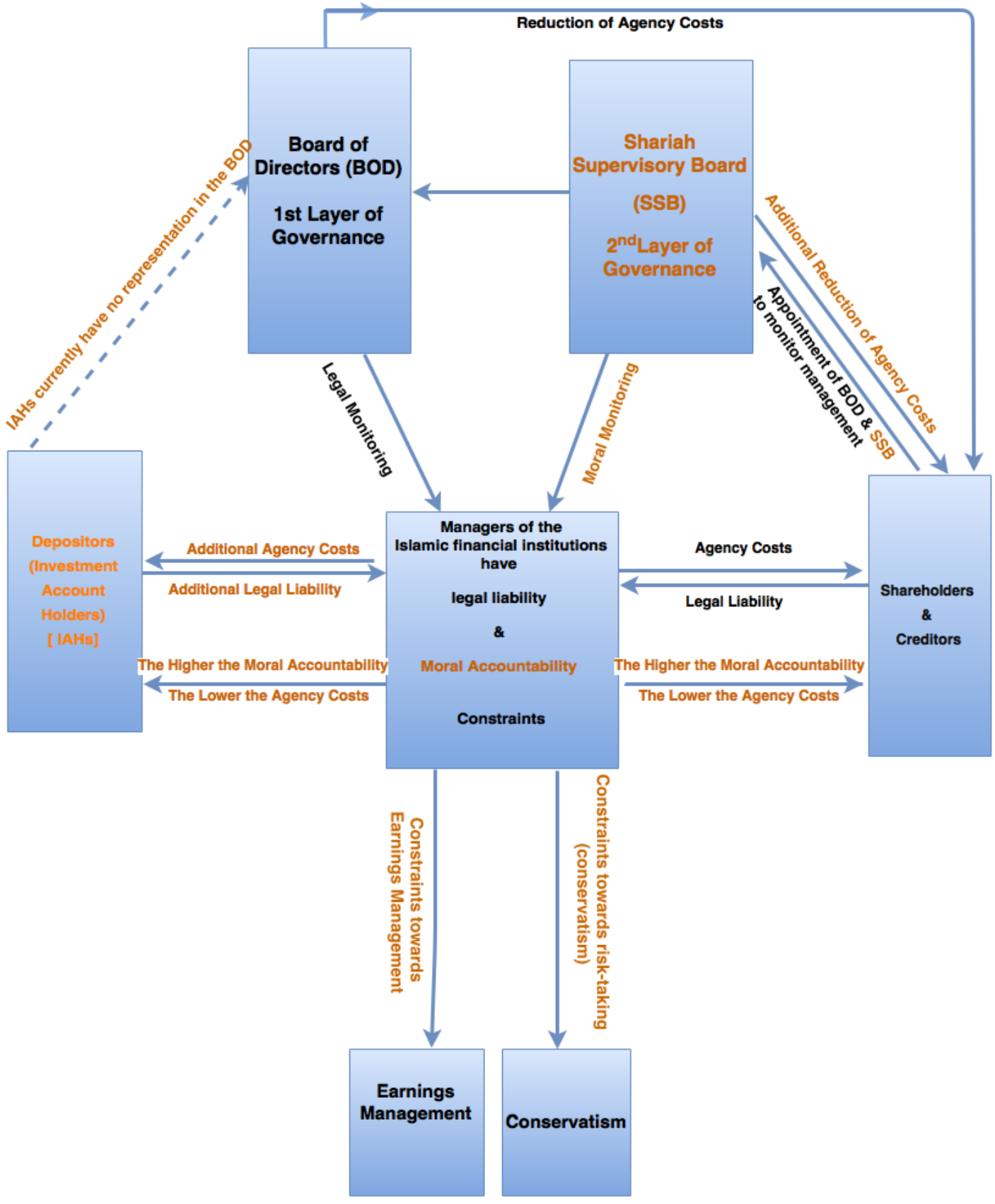


Table 1. A comparison between Islamic and conventional banking and finance

\begin{tabular}{|c|c|c|}
\hline Characteristics & Conventional Banking & Islamic Banking \\
\hline Constraints on finance model & None & $\begin{array}{l}\text { Prohibits Riba (usury), Gharar (excessive uncertainty), and Maysir (speculations). } \\
\text { Its theoretical model encourages the sharing of profits, losses, and risks in } \\
\text { investment activities. }\end{array}$ \\
\hline Prohibited activities & None & $\begin{array}{l}\text { Prohibits investment in businesses whose products or activities are contrary to } \\
\text { Islamic principles } \\
\text { (e.g. pork, alcohol, pornography, tobacco, weapons, of mass destruction, gambling, } \\
\text { cloning, and dangerous drugs). }\end{array}$ \\
\hline Types of depositors & Traditional depositors receive fixed returns (interest) & $\begin{array}{l}\text { Depositors are contracted as investment account holders (IAHs) who share in } \\
\text { profits, losses, and risks of the investments related to their deposits with the bank }\end{array}$ \\
\hline $\begin{array}{l}\text { Business model and investment } \\
\text { modes }\end{array}$ & $\begin{array}{c}\text { A risk-transfer model that is based on loans and interest- } \\
\text { bearing activities }\end{array}$ & $\begin{array}{l}\text { Encourages equity based financing instruments that are based on profit-loss sharing } \\
\text { contracts [such as Musharakah (partnership / joint venture), and Mudarabah } \\
\text { (partnership-based trust financing). There are other contracts that are allowed such } \\
\text { as Ijarah (lease) as well as Murabahah (cost plus profit sale)]. }\end{array}$ \\
\hline Corporate governance & $\begin{array}{c}\text { Conventional board of directors } \\
\text { (One layer of governance mechanisms) }\end{array}$ & $\begin{array}{l}\text { Conventional board of directors and Shariah supervisory board } \\
\text { (Two layers of governance mechanisms) }\end{array}$ \\
\hline Accountability constraints & Legal accountability constraints & Legal and moral accountability constraints \\
\hline
\end{tabular}


Table 2. Descriptive statistics of full sample

\begin{tabular}{|c|c|c|c|c|c|c|c|c|c|c|c|c|c|c|c|}
\hline & \multicolumn{5}{|c|}{ Full sample } & \multicolumn{5}{|c|}{ Islamic banks } & \multicolumn{5}{|c|}{ Conventional banks } \\
\hline Variables & Obs. & Mean & Std. Dev & Min & Max & Obs. & Mean & Std. Dev & Min & Max & Obs. & Mean & Std. Dev & Min & Max \\
\hline SPOS & 600 & 0.287 & 0.452 & 0 & 1 & 147 & 0.264 & 0.441 & 0 & 1 & 453 & 0.356 & 0.480 & 0 & 1 \\
\hline EM & 172 & 0.002 & 0.002 & -0.006 & 0.007 & 37 & 0.001 & 0.003 & -0.006 & 0.007 & 135 & 0.002 & 0.002 & -0.005 & 0.006 \\
\hline DACC & 581 & -0.039 & 0.145 & -2.144 & 0.449 & 142 & -0.039 & 0.137 & -2.144 & 0.183 & 439 & -0.041 & 0.167 & -1.121 & 0.449 \\
\hline EBT & 598 & 0.017 & 0.014 & -0.062 & 0.101 & 144 & 0.014 & 0.022 & -0.059 & 0.101 & 454 & 0.018 & 0.010 & -0.062 & 0.058 \\
\hline GOV_OWN & 597 & 0.231 & 0.237 & 0 & 0.948 & 143 & 0.170 & 0.161 & 0 & 0.651 & 454 & 0.250 & 0.254 & 0 & 0.948 \\
\hline FOR_OWN & 597 & 0.221 & 0.277 & 0 & 0.985 & 143 & 0.173 & 0.259 & 0 & 0.852 & 454 & 0.236 & 0.281 & 0 & 0.985 \\
\hline DUAL & 598 & 0.195 & 0.397 & 0 & 1 & 144 & 0.159 & 0.367 & 0 & 1 & 454 & 0.207 & 0.405 & 0 & 1 \\
\hline BODIND & 597 & 0.677 & 0.167 & 0 & 0.980 & 143 & 0.640 & 0.161 & 0.285 & 0.800 & 454 & 0.689 & 0.168 & 0 & 0.980 \\
\hline LLPs & 590 & 0.011 & 0.121 & -0.045 & 0.104 & 139 & 0.014 & 0.015 & -0.032 & 0.104 & 451 & 0.010 & 0.011 & -0.045 & 0.097 \\
\hline$\triangle \mathrm{NPL}$ & 528 & 0.008 & 0.061 & -0.457 & 1.097 & 126 & 0.004 & 0.053 & -0.457 & 0.112 & 402 & 0.009 & 0.064 & -0.161 & 1.097 \\
\hline NPL & 550 & 0.079 & 0.116 & 0.005 & 0.935 & 134 & 0.077 & 0.115 & 0.005 & 0.671 & 416 & 0.079 & 0.116 & 0.032 & 0.935 \\
\hline RET & 592 & -0.048 & 0.766 & -12.19 & 2.74 & 147 & -0.009 & 0.238 & -1.00 & -1.36 & 445 & -0.062 & 0.872 & -12.79 & 2.74 \\
\hline $\mathrm{LCO}$ & 501 & 0.006 & 0.013 & -0.040 & 0.102 & 118 & 0.005 & 0.013 & -0.040 & 0.098 & 383 & 0.006 & 0.013 & -0.026 & 0.102 \\
\hline LLA & 527 & 0.055 & 0.081 & 0 & 0.716 & 130 & 0.046 & 0.077 & 0 & 0.526 & 397 & 0.060 & 0.082 & 0 & 0.716 \\
\hline SIZE & 600 & 15.80 & 1.198 & 11.990 & 18.620 & 146 & 15.695 & 1.201 & 11.99 & 18.13 & 454 & 15.838 & 1.196 & 12.870 & 18.620 \\
\hline LEV & 595 & 8.150 & 5.664 & -62.640 & 58.090 & 143 & 6.825 & 4.128 & 0.010 & 19.63 & 452 & 8.569 & 6.012 & -62.64 & 58.090 \\
\hline CAP & 555 & 2.729 & 0.423 & 1.260 & 5.210 & 137 & 2.997 & 0.496 & 1.910 & 5.210 & 418 & 2.641 & 0.355 & 1.260 & 3.590 \\
\hline GRW & 600 & 1.439 & 0.822 & -0.064 & 6.532 & 146 & 1.420 & 1.041 & 0.001 & 6.533 & 454 & 1.446 & 0.740 & -0.064 & 5.250 \\
\hline $\mathrm{CFO}$ & 594 & 0.305 & 4.571 & -27.810 & 78.940 & 143 & 0.843 & 7.546 & -0.581 & 78.940 & 451 & 0.135 & 3.073 & -27.81 & 56.220 \\
\hline AUDQ & 600 & 0.896 & 0.304 & 0 & 1 & 146 & 0.976 & 0.163 & 0 & 1 & 454 & 0.872 & 0.334 & 0 & 1 \\
\hline GCC & 600 & 0.590 & 0.492 & 0 & 1 & 146 & 0.876 & 0.339 & 0 & 1 & 454 & 0.498 & 0.500 & 0 & 1 \\
\hline TURC & 600 & 0.190 & 0.392 & 0 & 1 & 146 & 0.041 & 0.199 & 0 & 1 & 454 & 0.237 & 0.426 & 0 & 1 \\
\hline CORRUPT & 600 & 58.259 & 20.449 & 10.520 & 92.344 & 146 & 57.270 & 20.410 & 10.800 & 90.440 & 454 & 58.163 & 20.511 & 10.526 & 92.344 \\
\hline
\end{tabular}

SPOS is a dummy encoded 1 if the ratio of net income to lagged total assets is between 0 and 0.01 , and 0 otherwise. EM is the difference between the discretionary part of realized security gains and losses and the discretionary part of loan loss provisions. DACC are the discretionary accruals measured based on Jones (1991) model as modified by Yasuda et al. (2004). EBT is earnings before taxes deflated by lagged total assets. GOV_OWN is the percentage of shares held by government or government bodies. FOR_OWN is the percentage of shares held by foreign investors. DUAL is a dummy encoded 1 for CEO duality, 0 otherwise. BODIND is the ratio of independent members over the number of board members. LLPs is the ratio of loan loss provisions for year $t$ to total loans in year $t-1$. $\Delta \mathrm{NPL}$ is the change in nonperforming loans between year $t$ and 
t-1 deflated by total loans in year t-1. RET is the annual buy-and-hold stock return. NPL is the level of nonperforming loans deflated by total loans in year t-1.LCO is the loan charge-offs for year t deflated by total loans in year t-1. SIZE is the natural logarithm of year-end total assets. LEV is the ratio of total debt to total common equity. CAP is the ratio of actual regulatory capital (Tier 1 capital) to the minimum required regulatory capital. GRW is the ratio of market-to-book value of equity. AUDQ is a dummy encoded 1 if auditor is a Big Four, 0 otherwise. CFO is cash flow from operating activities deflated by average total assets. LLA is the ratio of loan loss allowances at the end of year $t$ to total loans. GCC is a dummy encoded 1 if a bank is based in Oman, Qatar, UAE, Bahrain, Saudi Arabia, or Kuwait, 0 otherwise. TURC is a dummy encoded 1 if a bank is based in Egypt, Syria, or Tunisia, 0 otherwise. CORRUPT is the control of corruption, which captures perceptions of the extent to which public power is exercised for private gain, including both petty and grand forms of corruption, as well as "capture" of the state by elites and private interests. Percentile rank indicates the country's rank among all countries covered by the aggregate indicator, with 0 corresponding to the lowest rank, and 100 to the highest rank. 
Table 3. Pearson correlation coefficients among sample variables

Panel A. Variables used on earnings management models

\begin{tabular}{|c|c|c|c|c|c|c|c|c|c|c|c|c|c|c|c|c|c|c|}
\hline Variables & 1 & 2 & 3 & 4 & 5 & 6 & 7 & 8 & 9 & 10 & 11 & 12 & 13 & 14 & 15 & 16 & 17 & 18 \\
\hline 1.SPOS & 1 & & & & & & & & & & & & & & & & & \\
\hline 2.EM & -0.04 & 1 & & & & & & & & & & & & & & & & \\
\hline 3.DACC & -0.12 & -0.03 & 1 & & & & & & & & & & & & & & & \\
\hline 4.EBT & -0.28 & -0.08 & -0.23 & 1 & & & & & & & & & & & & & & \\
\hline 5.IBs & -0.15 & -0.08 & -0.01 & 0.001 & 1 & & & & & & & & & & & & & \\
\hline 6.GOV_OWN & -0.05 & 0.13 & -0.03 & -0.07 & -0.14 & 1 & & & & & & & & & & & & \\
\hline 7.FOR_OWN & 0.02 & -0.28 & 0.09 & -0.08 & -0.09 & -0.04 & 1 & & & & & & & & & & & \\
\hline 8.DUAL & 0.01 & -0.27 & 0.02 & -0.03 & -0.05 & -0.06 & 0.04 & 1 & & & & & & & & & & \\
\hline 9.BODIND & -0.06 & 0.08 & -0.02 & 0.10 & -0.12 & 0.24 & 0.04 & -0.18 & 1 & & & & & & & & & \\
\hline 10.SIZE & -0.17 & 0.44 & -0.17 & 0.01 & -0.05 & 0.07 & -0.24 & -0.09 & -0.07 & 1 & & & & & & & & \\
\hline 11.LEV & 0.15 & -0.19 & -0.01 & 0.02 & -0.10 & -0.11 & 0.16 & 0.09 & -0.11 & 0.13 & 1 & & & & & & & \\
\hline 12.CAP & -0.04 & -0.17 & -0.03 & 0.22 & 0.37 & 0.15 & -0.06 & -0.15 & 0.09 & -0.27 & -0.64 & 1 & & & & & & \\
\hline 13.GRW & -0.08 & 0.13 & -0.04 & 0.33 & -0.01 & -0.20 & -0.07 & 0.01 & -0.07 & 0.10 & 0.22 & -0.08 & 1 & & & & & \\
\hline 14.AUDQ & -0.14 & 0.15 & -0.05 & 0.13 & 0.14 & -0.15 & 0.01 & -0.11 & -0.04 & 0.21 & -0.09 & 0.24 & 0.15 & 1 & & & & \\
\hline $15 . \mathrm{CFO}$ & -0.04 & 0.08 & -0.03 & -0.02 & 0.06 & -0.03 & -0.02 & -0.04 & -0.02 & 0.06 & 0.02 & -0.04 & 0.02 & 0.02 & 1 & & & \\
\hline 16.GCC & -0.14 & 0.57 & -0.09 & 0.12 & 0.33 & 0.10 & -0.38 & -0.33 & 0.09 & 0.38 & -0.20 & 0.25 & 0.11 & 0.40 & 0.05 & 1 & & \\
\hline 17.TURC & 0.08 & -0.28 & 0.05 & -0.11 & -0.21 & 0.08 & 0.14 & 0.21 & -0.10 & -0.35 & 0.10 & -0.26 & -0.14 & -0.59 & -0.03 & -0.58 & 1 & \\
\hline 18.CORRUPT & -0.04 & -0.11 & 0.04 & 0.12 & -0.04 & -0.07 & 0.05 & 0.03 & 0.00 & 0.03 & 0.07 & -0.08 & 0.12 & 0.13 & 0.02 & 0.03 & -0.06 & 1 \\
\hline
\end{tabular}

Coefficients in bold indicate statistical significance at the $5 \%$ significance level or more. 
Panel B. Variables used on the conditional conservatism model

\begin{tabular}{|c|c|c|c|c|c|c|c|c|c|c|c|c|c|c|c|c|c|c|c|c|c|}
\hline Variables & 1 & 2 & 3 & 4 & 5 & 6 & 7 & 8 & 9 & 10 & 11 & 12 & 13 & 14 & 15 & 16 & 17 & 18 & 19 & 20 & 21 \\
\hline 1.LLPs & 1 & & & & & & & & & & & & & & & & & & & & \\
\hline 2. $\Delta$ NPLt-1 & 0.02 & 1 & & & & & & & & & & & & & & & & & & & \\
\hline $3 . \Delta \mathrm{NPLt}$ & 0.04 & -0.09 & 1 & & & & & & & & & & & & & & & & & & \\
\hline 4. $\Delta \mathrm{NPLt}+1$ & -0.16 & 0.27 & -0.09 & 1 & & & & & & & & & & & & & & & & & \\
\hline 5.LCO & 0.12 & -0.02 & -0.02 & 0.03 & 1 & & & & & & & & & & & & & & & & \\
\hline 6.LCOt+1 & 0.15 & 0.06 & -0.01 & -0.02 & 0.46 & 1 & & & & & & & & & & & & & & & \\
\hline 7.IBs & 0.08 & -0.01 & -0.02 & -0.03 & 0.00 & -0.03 & 1 & & & & & & & & & & & & & & \\
\hline 8.GOV_OWN & 0.06 & -0.01 & -0.03 & -0.03 & -0.07 & -0.05 & -0.14 & 1 & & & & & & & & & & & & & \\
\hline 9.FOR_OWN & -0.02 & -0.05 & -0.03 & -0.03 & -0.02 & 0.02 & -0.09 & -0.05 & 1 & & & & & & & & & & & & \\
\hline 10.DUAL & -0.01 & 0.03 & -0.02 & 0.04 & 0.04 & -0.01 & -0.05 & -0.06 & 0.04 & 1 & & & & & & & & & & & \\
\hline 11.BODIND & -0.04 & -0.01 & -0.04 & -0.00 & -0.14 & -0.04 & -0.12 & 0.24 & 0.03 & -0.18 & 1 & & & & & & & & & & \\
\hline 12.SIZE & -0.06 & 0.02 & 0.03 & 0.00 & -0.05 & -0.03 & -0.06 & 0.07 & -0.24 & -0.09 & -0.07 & 1 & & & & & & & & & \\
\hline 13.LEV & -0.22 & 0.05 & 0.07 & 0.09 & 0.02 & 0.04 & -0.10 & -0.11 & 0.16 & 0.09 & -0.11 & 0.13 & 1 & & & & & & & & \\
\hline 14.CAP & -0.02 & -0.10 & -0.17 & -0.14 & -0.02 & -0.06 & 0.36 & 0.16 & -0.06 & -0.15 & 0.08 & -0.27 & -0.54 & 1 & & & & & & & \\
\hline 15.GRW & -0.21 & -0.04 & -0.02 & -0.02 & 0.02 & -0.01 & -0.01 & -0.20 & -0.07 & 0.01 & -0.07 & 0.10 & 0.22 & -0.08 & 1 & & & & & & \\
\hline 16.AUDQ & -0.13 & 0.05 & 0.05 & 0.08 & 0.04 & 0.01 & 0.14 & -0.15 & 0.00 & -0.11 & -0.04 & 0.21 & -0.09 & 0.24 & 0.15 & 1 & & & & & \\
\hline 17.CFO & 0.01 & -0.01 & -0.02 & -0.01 & -0.00 & 0.01 & 0.06 & -0.03 & -0.02 & -0.04 & -0.02 & 0.06 & 0.02 & -0.04 & 0.02 & -0.00 & 1 & & & & \\
\hline 18.LLA & 0.27 & -0.01 & -0.02 & -0.07 & 0.11 & 0.17 & -0.06 & 0.14 & 0.17 & 0.15 & 0.05 & -0.30 & -0.01 & -0.02 & -0.11 & -0.39 & -0.02 & 1 & & & \\
\hline 19.GCC & 0.04 & 0.01 & 0.01 & 0.01 & -0.03 & -0.03 & 0.33 & 0.10 & -0.38 & -0.33 & 0.09 & 0.39 & -0.20 & 0.25 & 0.11 & -0.40 & 0.05 & -0.30 & 1 & & \\
\hline 20.TURC & 0.15 & -0.06 & -0.07 & -0.04 & 0.01 & 0.01 & -0.21 & 0.08 & 0.14 & 0.21 & -0.10 & -0.35 & 0.10 & -0.26 & -0.14 & -0.49 & -0.03 & 0.49 & -0.58 & 1 & \\
\hline 21.CORRUPT & -0.03 & 0.04 & 0.06 & -0.05 & -0.04 & 0.04 & -0.04 & -0.07 & 0.05 & 0.03 & 0.00 & 0.03 & 0.07 & -0.08 & 0.12 & 0.13 & 0.02 & 0.01 & 0.03 & -0.06 & 1 \\
\hline
\end{tabular}

Coefficients in bold indicate statistical significance at the $5 \%$ significance level or more.

SPOS is a dummy encoded 1 if the ratio of net income to lagged total assets is between 0 and 0.01 , and 0 otherwise. EM is the difference between the discretionary part of realized security gains and losses and the discretionary part of loan loss provisions. DACC are the discretionary accruals measured based on Jones (1991) model as modified by Yasuda et al. (2004). EBT is earnings before taxes deflated by lagged total assets. GOV_OWN is the percentage of shares held by government or government bodies. FOR_OWN is the percentage of shares held by foreign investors. DUAL is a dummy encoded 1 for CEO duality, 0 otherwise. BODIND is the ratio of independent members over the number of board members. LLPs is the ratio of loan loss provisions for year $t$ to total loans in year $\mathrm{t}-1$. $\Delta \mathrm{NPL}$ is the change in nonperforming loans between year $\mathrm{t}$ and $\mathrm{t}-1$ deflated by total loans in year $\mathrm{t}-1$ for the current previous and future period. LCO is the loan charge-offs for year $\mathrm{t}$ deflated by total loans in year $\mathrm{t}-1$ for the current and future period. IBs is a dummy encoded 1 if the bank is classified as Islamic, 0 otherwise. SIZE is the natural logarithm of year-end total assets. LEV is the ratio of total debt to 
total common equity. CAP is the ratio of actual regulatory capital (Tier 1 capital) to the minimum required regulatory capital. GRW is the ratio of market-to-book value of equity. AUDQ is a dummy encoded 1 if auditor is a Big Four, 0 otherwise. CFO is cash flow from operating activities deflated by average total assets. LLA is the ratio of loan loss allowances at the end of year $t$ to total loans. GCC is a dummy encoded 1 if a bank is based in Oman, Qatar, UAE, Bahrain, Saudi Arabia, or Kuwait, 0 otherwise. TURC is a dummy encoded 1 if a bank is based in Egypt, Syria, or Tunisia, 0 otherwise. CORRUPT is the control of corruption, which captures perceptions of the extent to which public power is exercised for private gain, including both petty and grand forms of corruption, as well as "capture" of the state by elites and private interests. Percentile rank indicates the country's rank among all countries covered by the aggregate indicator, with 0 corresponding to the lowest rank, and 100 to the highest rank. 
Table 4. Conditional conservatism in Islamic banks and conventional banks

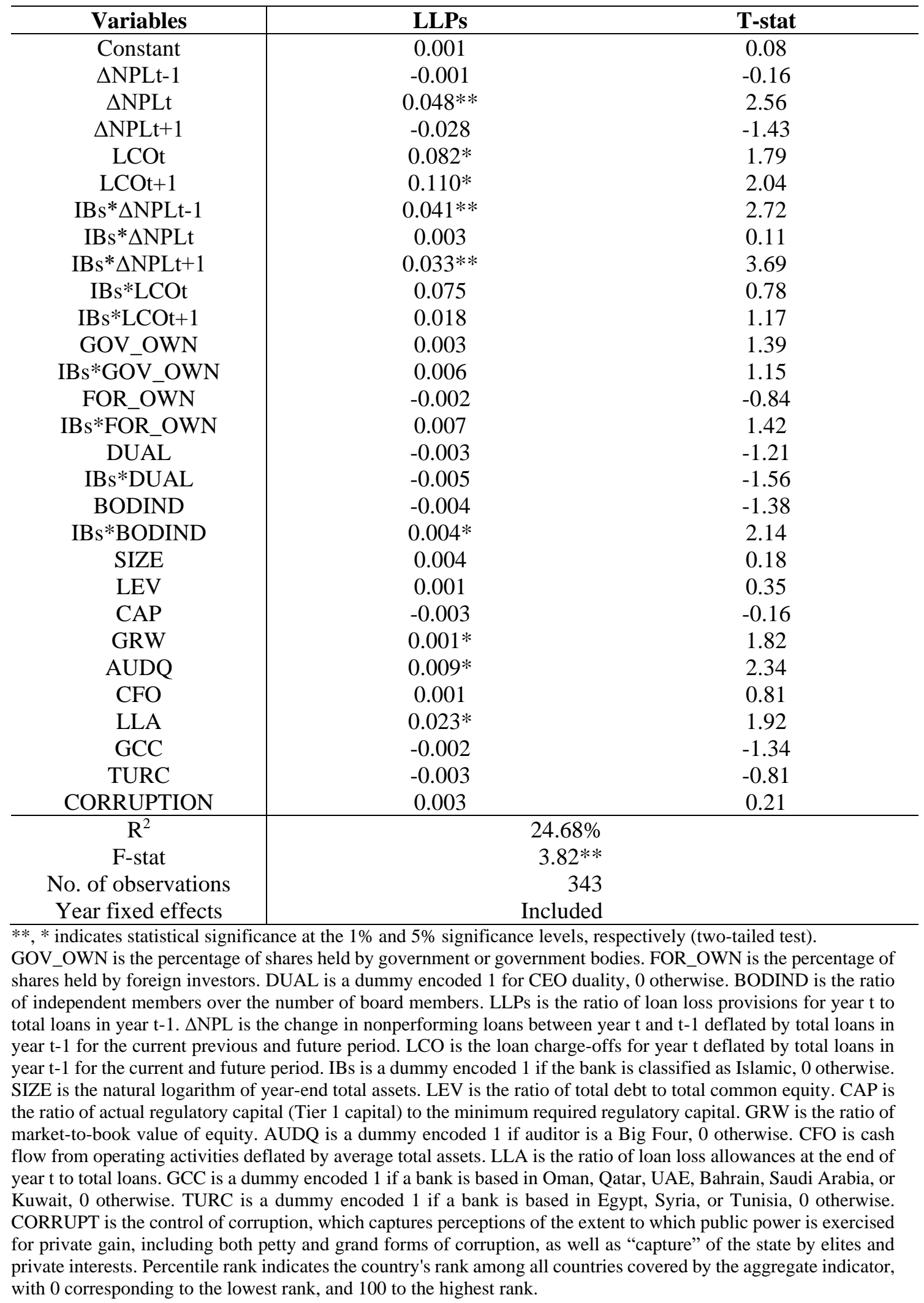


Table 5. Regression results on earnings management in Islamic banks and conventional banks

\begin{tabular}{|c|c|c|c|c|}
\hline Variables & SPOS & & EM & DACC \\
\hline Constant & $\begin{array}{c}7.062 * * \\
(2.63)\end{array}$ & & $\begin{array}{l}0.003 \\
(0.97)\end{array}$ & $\begin{array}{l}0.411 * * \\
(3.05)\end{array}$ \\
\hline EBT & $\begin{array}{c}0.145^{* *} \\
(7.17)\end{array}$ & & $\begin{array}{l}0.007 \\
(0.36)\end{array}$ & $\begin{array}{l}1.345^{*} \\
(1.82)\end{array}$ \\
\hline $\mathrm{IBs} * \mathrm{EBT}$ & $\begin{array}{c}-0.885^{* *} \\
(-3.55)\end{array}$ & & $\begin{array}{c}-0.049 * \\
(-1.79)\end{array}$ & $\begin{array}{c}-0.551 * * \\
(-3.60)\end{array}$ \\
\hline GOV_OWN & $\begin{array}{c}-0.002^{*} \\
(-2.38)\end{array}$ & & $\begin{array}{l}0.003 \\
(0.63)\end{array}$ & $\begin{array}{l}-0.009^{*} \\
(-2.31)\end{array}$ \\
\hline IBs*GOV_OWN & $\begin{array}{l}0.001 \\
(0.12)\end{array}$ & & $\begin{array}{l}0.001 \\
(0.28)\end{array}$ & $\begin{array}{l}-0.001 \\
(-1.53)\end{array}$ \\
\hline FOR_OWN & $\begin{array}{l}0.002 \\
(0.48)\end{array}$ & & $\begin{array}{l}0.005^{*} \\
(1.84)\end{array}$ & $\begin{array}{l}0.001 \\
(0.44)\end{array}$ \\
\hline IBs*FOR_OWN & $\begin{array}{c}-0.003 * * \\
(-2.93)\end{array}$ & & $\begin{array}{c}-0.046^{* *} \\
(2.33)\end{array}$ & $\begin{array}{l}0.008 \\
(0.15)\end{array}$ \\
\hline DUAL & $\begin{array}{l}-0.251 \\
(-0.71)\end{array}$ & & $\begin{array}{l}0.009^{*} \\
(1.97)\end{array}$ & $\begin{array}{l}0.006 \\
(0.35)\end{array}$ \\
\hline IBs*DUAL & $\begin{array}{l}0.506 \\
(0.67)\end{array}$ & & $\begin{array}{c}-0.003 \\
(-0.023)\end{array}$ & $\begin{array}{l}0.051 \\
(1.28)\end{array}$ \\
\hline BODIND & $\begin{array}{l}0.292 \\
(0.39)\end{array}$ & & $\begin{array}{l}0.007 * \\
(1.78)\end{array}$ & $\begin{array}{l}0.009 \\
(0.25)\end{array}$ \\
\hline IBs*BODIND & $\begin{array}{l}-0.675 \\
(-0.73)\end{array}$ & & $\begin{array}{l}-0.003^{*} \\
(-2.10)\end{array}$ & $\begin{array}{l}0.037 \\
(0.76)\end{array}$ \\
\hline SIZE & $\begin{array}{c}-0.368 * * \\
(-2.86)\end{array}$ & & $\begin{array}{l}0.002 \\
(1.39)\end{array}$ & $\begin{array}{c}-0.019 * * \\
(-3.04)\end{array}$ \\
\hline LEV & $\begin{array}{l}0.057 \\
(1.64)\end{array}$ & & $\begin{array}{l}0.001^{*} \\
(1.97)\end{array}$ & $\begin{array}{l}0.002 \\
(1.31)\end{array}$ \\
\hline CAP & $\begin{array}{l}0.052 \\
(0.13)\end{array}$ & & $\begin{array}{l}0.002^{*} \\
(2.39)\end{array}$ & $\begin{array}{l}0.028 \\
(1.36)\end{array}$ \\
\hline GRW & $\begin{array}{l}-0.021 \\
(-0.14)\end{array}$ & & $\begin{array}{l}0.001 \\
(1.26)\end{array}$ & $\begin{array}{l}0.003 \\
(0.05)\end{array}$ \\
\hline AUDQ & $\begin{array}{l}0.164 \\
(0.34)\end{array}$ & & $\begin{array}{l}-0.001 \\
(-0.17)\end{array}$ & $\begin{array}{l}-0.010 \\
(-0.39)\end{array}$ \\
\hline $\mathrm{CFO}$ & $\begin{array}{l}-0.036 \\
(-1.01)\end{array}$ & & $\begin{array}{l}0.001 \\
(0.56)\end{array}$ & $\begin{array}{l}-0.002 \\
(-0.68)\end{array}$ \\
\hline GCC & $\begin{array}{l}-0.712^{*} \\
(-1.91)\end{array}$ & & $\begin{array}{c}0.002 * * \\
(4.49)\end{array}$ & $\begin{array}{l}-0.009 \\
(-0.47)\end{array}$ \\
\hline TURC & $\begin{array}{l}-0.659 \\
(-1.51)\end{array}$ & & $\begin{array}{l}-0.001 \\
(-0.02)\end{array}$ & $\begin{array}{l}-0.017 \\
(-0.76)\end{array}$ \\
\hline CORRUPTION & $\begin{array}{l}0.014 \\
(0.18) \\
\end{array}$ & & $\begin{array}{l}0.025 \\
(0.09) \\
\end{array}$ & $\begin{array}{l}0.006 \\
(0.14) \\
\end{array}$ \\
\hline $\begin{array}{l}\mathrm{R}^{2} \mathrm{~L} \\
\mathrm{X}^{2}\end{array}$ & $\begin{array}{l}23.47 \% \\
14962 * *\end{array}$ & $\mathrm{R}^{2}$-adj & $\begin{array}{l}55.05 \% \\
0.87 * *\end{array}$ & $27.56 \%$ \\
\hline No. of observations & $\begin{array}{l}149.033^{*-n} \\
545\end{array}$ & $\begin{array}{l}\text { F-stat } \\
\text { No. of observations }\end{array}$ & $\begin{array}{c}9.8 / 2 \\
164\end{array}$ & 530 \\
\hline
\end{tabular}

T-statistics are in the parentheses except for the SPOS model which presents z- statistics. **, * indicate statistical significance at the $1 \%$ and 5\% significance levels, respectively (two-tailed test). SPOS is a dummy encoded 1 if the ratio of net income to lagged total assets is between 0 and 0.01 , and 0 otherwise. EM is the difference between the discretionary part of realized security gains and losses and the discretionary part of loan loss provisions. DACC are the discretionary accruals measured based on Jones (1991) model as modified by Yasuda et al. (2004). EBT is 
earnings before taxes deflated by lagged total assets. GOV_OWN is the percentage of shares held by government or government bodies. FOR_OWN is the percentage of shares held by foreign investors. DUAL is a dummy encoded 1 for CEO duality, 0 otherwise. BODIND is the ratio of independent members over the number of board members. IBs is a dummy encoded 1 if the bank is classified as Islamic, 0 otherwise. SIZE is the natural logarithm of year-end total assets. LEV is the ratio of total debt to total common equity. CAP is the ratio of actual regulatory capital (Tier 1 capital) to the minimum required regulatory capital. GRW is the ratio of market-to-book value of equity. AUDQ is a dummy encoded 1 if auditor is a Big Four, 0 otherwise. CFO is cash flow from operating activities deflated by average total assets. GCC is a dummy encoded 1 if a bank is based in Oman, Qatar, UAE, Bahrain, Saudi Arabia, or Kuwait, 0 otherwise. TURC is a dummy encoded 1 if a bank is based in Egypt, Syria, or Tunisia, 0 otherwise. CORRUPT is the control of corruption, which captures perceptions of the extent to which public power is exercised for private gain, including both petty and grand forms of corruption, as well as "capture" of the state by elites and private interests. Percentile rank indicates the country's rank among all countries covered by the aggregate indicator, with 0 corresponding to the lowest rank, and 100 to the highest rank. 
Table 6. Logistic regression result for audit selection

\begin{tabular}{c|c}
\hline Variables & AUDQ \\
\hline Constant & $5.780^{*}$ \\
EBT & $(2.26)$ \\
& $0.954^{*}$ \\
IBs & $(7.09)$ \\
& $0.109^{*}$ \\
GOV_OWN & $(2.35)$ \\
& -0.002 \\
FOR_OWN & $(-0.55)$ \\
DUAL & 0.009 \\
& $\left(-2.08^{*}\right)$ \\
BODIND & 0.189 \\
& $(0.64)$ \\
SIZE & -0.129 \\
LEV & $(-0.18)$ \\
CAP & $0.327 *$ \\
& $(2.64)$ \\
GRW & -0.058 \\
& $(-1.55)$ \\
CFO & 0.103 \\
& $(0.27)$ \\
GCC & 0.045 \\
TURC & $(0.32)$ \\
No. of observations & -0.033 \\
Year fixed effects & $(-0.91)$ \\
& $0.653^{*}$ \\
& $(1.93)$ \\
& $-0.539^{* *}$ \\
& $(-1.45)$ \\
\hline Zscluded \\
\hline
\end{tabular}

$\bar{Z}$-statistics are in the parentheses. $* *, *$ indicate statistical significance at the $1 \%$ and $5 \%$ significance levels, respectively (two-tailed test). EBT is earnings before taxes deflated by lagged total assets. GOV_OWN is the percentage of shares held by government or government bodies. FOR_OWN is the percentage of shares held by foreign investors. DUAL is a dummy encoded 1 for CEO duality, 0 otherwise. BODIND is the ratio of independent members over the number of board members. IBs is a dummy encoded 1 if the bank is classified as Islamic, 0 otherwise. SIZE is the natural logarithm of year-end total assets. LEV is the ratio of total debt to total common equity. CAP is the ratio of actual regulatory capital (Tier 1 capital) to the minimum required regulatory capital. GRW is the ratio of market-to-book value of equity. AUDQ is a dummy encoded 1 if auditor is a Big Four, 0 otherwise. CFO is cash flow from operating activities deflated by average total assets. GCC is a dummy encoded 1 if a bank is based in Oman, Qatar, UAE, Bahrain, Saudi Arabia, or Kuwait, 0 otherwise. TURC is a dummy encoded 1 if a bank is based in Egypt, Syria, or Tunisia, 0 otherwise. 


\section{APPENDIX A}

Distribution of listed banks by country and specialization

\begin{tabular}{|l|c|c|c|}
\hline \multicolumn{1}{|c|}{ Country } & No. of Banks & Islamic Banks & Commercial Banks \\
\hline Bahrain & 8 & 5 & 3 \\
\hline Egypt & 10 & 1 & 9 \\
\hline Jordan & 11 & 2 & 9 \\
\hline Kuwait & 8 & 4 & 4 \\
\hline Lebanon & 5 & 0 & 5 \\
\hline Morocco & 6 & 0 & 6 \\
\hline Oman & 6 & 0 & 6 \\
\hline Qatar & 7 & 3 & 4 \\
\hline Saudi Arabia & 11 & 4 & 7 \\
\hline Syria & 8 & 0 & 8 \\
\hline Tunisia & 1 & 0 & 1 \\
\hline UAE & 19 & 5 & $\mathbf{7 6}$ \\
\hline Total & $\mathbf{1 0 0}$ & $\mathbf{2 4}$ & \\
\hline
\end{tabular}




\section{APPENDIX B}

\section{Definitions of Variables}

\begin{tabular}{|c|c|}
\hline Variables & Definition \\
\hline LLPs & Ratio of loan loss provisions for year $\mathrm{t}$ to total loans in year $\mathrm{t}-1$ \\
\hline$\triangle \mathrm{NPL}$ & $\begin{array}{l}\text { Change in nonperforming loans between year } \mathrm{t} \text { and } \mathrm{t}-1 \text { deflated by } \\
\text { total loans in year } \mathrm{t}-1\end{array}$ \\
\hline $\mathrm{LCO}$ & Loan charge-offs for year $\mathrm{t}$ deflated by total loans in year $\mathrm{t}-1$ \\
\hline IBs & A dummy encoded 1 if the bank is classified as Islamic, 0 otherwise \\
\hline SPOS & $\begin{array}{l}\text { A dummy encoded } 1 \text { if the ratio of net income to lagged total assets } \\
\text { is between } 0 \text { and } 0.01 \text {, and } 0 \text { otherwise }\end{array}$ \\
\hline EM & $\begin{array}{l}\text { The difference between the discretionary part of realized security } \\
\text { gains and losses and the discretionary part of loan loss provisions }\end{array}$ \\
\hline DACC & $\begin{array}{l}\text { Discretionary accruals measured based on the Jones (1991) model, } \\
\text { as modified by Yasuda et al. (2004) }\end{array}$ \\
\hline EBT & Earnings before taxes deflated by lagged total assets \\
\hline GOV_OWN & The percentage of shares held by government or government bodies \\
\hline FOR_OWN & The percentage of shares held by foreign investors \\
\hline DUAL & A dummy encoded 1 for CEO duality, 0 otherwise \\
\hline BODIND & $\begin{array}{l}\text { The ratio of independent members over the number of board } \\
\text { members }\end{array}$ \\
\hline SIZE & Natural logarithm of year-end total assets \\
\hline LEV & Ratio of total debt to total common equity \\
\hline CAP & $\begin{array}{l}\text { Ratio of actual regulatory capital (Tier } 1 \text { capital) to the minimum } \\
\text { required regulatory capital }\end{array}$ \\
\hline GRW & Ratio of market-to-book value of equity \\
\hline AUDQ & A dummy encoded 1 if auditor is a Big Four, 0 otherwise \\
\hline $\mathrm{CFO}$ & Cash flow from operating activities deflated by average total assets \\
\hline LLA & Ratio of loan loss allowances at the end of year $t$ to total loans \\
\hline GCC & $\begin{array}{l}\text { A dummy encoded } 1 \text { if a bank is based in Oman, Qatar, UAE, } \\
\text { Bahrain, Saudi Arabia, or Kuwait, } 0 \text { otherwise }\end{array}$ \\
\hline TURC & $\begin{array}{l}\text { A dummy encoded } 1 \text { if a bank is based in Egypt, Syria, or Tunisia, } \\
0 \text { otherwise }\end{array}$ \\
\hline CORRUPT & $\begin{array}{l}\text { Control of corruption captures perceptions of the extent to which } \\
\text { public power is exercised for private gain, including both petty and } \\
\text { grand forms of corruption, as well as "capture" of the state by elites } \\
\text { and private interests. Percentile rank indicates the country's rank } \\
\text { among all countries covered by the aggregate indicator, with } 0 \\
\text { corresponding to the lowest rank, and } 100 \text { to the highest rank. }\end{array}$ \\
\hline
\end{tabular}

